\title{
Trust in Banks: Evidence from the Spanish Financial Crisis
}

\author{
Santiago Carbó-Valverde* \\ (Bangor Business School and Funcas) \\ Eduardo Maqui-López \\ (University of Granada and Funcas) \\ Francisco Rodríguez-Fernández \\ (University of Granada and Funcas)
}

\begin{abstract}
In this article we assess the economic problem of trust in financial institutions employing unique survey evidence from Spanish bank customers. Almost no studies have been able to evaluate the impact of bank customers' perceptions about financial institutions on trust in the financial system, controlling simultaneously for the underlying levels of general distrust. In order to fill in this gap, we study the potential impact of factors that might determine the level of trust in banks and analyse the effects of the perception of the 2007 financial crisis by bank customers. Allowing for bank customer heterogeneity and controlling for general distrust, we show that trust in banks is mainly affected by bank customers' assessment of several performance characteristics and attributes of banks. Our results suggest that for the sub-population of bank customers with neutral levels of general distrust -who also consider that Spanish financial institutions are changing their behaviour for the worse- an increase in banks' sensitivity towards customers' problems and banks' commitment to their customers would increase their probability of trusting banks by $34.7 \%$ and $34 \%$, respectively.
\end{abstract}

Keywords: Financial Crisis, Trust in Banks, Financial Services, Distrust. JEL Codes: G01, G02, G20, D03, D12, D14.

\footnotetext{
* Email: s.carbo-valverde@ bangor.ac.uk. Telephone: +44 (0) 1248 388852. Address: Bangor Business School, Hen Goleg, College Road, Bangor, LL57 2DG, Gwynedd, UK.

^ Email: edumaqui@ugr.es. Telephone: +34 958 249606. Address: Universidad de Granada, Facultad de Ciencias Económicas y Empresariales, Campus de Cartuja, Granada, 18071, Andalucía, Spain.

- Email: franrod@ugr.es. Telephone: +34 958 248346. Address: Universidad de Granada, Facultad de Ciencias Económicas y Empresariales, Campus de Cartuja, Granada, 18071, Andalucía, Spain.
} 


\section{Introduction}

Trust in banks has declined rapidly since the onset of the 2007 financial crisis and rebuilding trust appears to be one of the top priorities within the banking system today. ${ }^{1}$ In order to contain this unprecedented decline of trust in financial institutions, regulatory measures and supervisory initiatives are being continuously undertaken by authorities. However, the increasing pressure of regulation does not appear to have an immediate effect toward restoring trust in banks, whilst it might lead banks to lose their ability to operate effectively. Trust in banks seems to be more related to bank customers' insight of what a bank is; their judgement of the way in which a bank operates and their perception of different bank characteristics. Trust is based on the bank customers' belief that financial institutions take actions and decisions on their behalf, with the expectation that these do not violate their "vote of confidence given" (Gill et al., 2006).

However, little is known about the relationship between customers' perceptions of bank attributes and trust in financial institutions. Moreover, it is unlikely that bank customers' level of trust in financial institutions simply relies on their sociodemographic background or the economic environment, without considering attributes that specifically characterize the bank they operate with. Which attributes foster trust in banks? To what extent can a potential loss of trust in banks due to a financial crisis be offset by bank customers' perceptions of such attributes? The answers to these questions are important for the debate on how to rebuild trust in banks and may have major policy implications regarding the delivery of bank services.

Empirical evidence on which banks' characteristics decide the level of trust in the financial system is relatively hard to come by, despite how often it is publically discussed. The answer to this question is of most importance for the debate regarding the delivery of financial services by banks and the welfare consequences of the way in which they carry out their activity. This paper aims to grasp a better understanding of the relationship between trust in banks and several attributes that characterize financial institutions, by studying trust in the Spanish financial system.

\footnotetext{
${ }^{1}$ The Gallup analysis of confidence in institutions has recently revealed a trust crisis in the U.S. banking industry. In October 2010, the number of Americans expressing a "great deal" or "quite a lot" of confidence in banks fell to an all-time low of $18 \%$, what seems to be a continuation of a free fall that began in 2006.
} 
In light of how important this issue is, and the scarcity of evidence available, our paper analyses how the perception of specific attributes and characteristics of banks affect individuals' trust in financial institutions in Spain. The main objective we have is to define which of these features bank customers value the most, and are therefore positively related to trust in the financial system, and also to analyse whether these features helped to compensate the potential drop in the level of trust in banks due to the 2007 financial crisis. Our intention is to quantify to what extent the financial crisis has affected trust in Spanish financial institutions, and to what extent certain banks' features can help to balance such a decline.

By using a unique survey data set that contains detailed information about Spanish bank customers' trust in financial institutions and their judgment of several bank attributes, we estimate the effects of the perception of several bank characteristics on the level of trust that bank customers have in their own financial institution. More specifically, we analyse the extent to which the parameters regarding the bank-customer relationship foster trust in financial institutions. The survey provides information about the specific level of trust in banks -measured by the level of bank customers' trust in the solvency of commercial banks/savings banks in general, and of their own commercial bank/savings bank in particular- and also about the general level of individual distrust -proxied by the level of bank customers' distrust in people they do not have a close relationship with-. Our data also provides a number of variables that are related to the perception that bank customers' have regarding several characteristics and attributes of their own bank -in terms of sensitivity, efficiency, service, social activities, comfort and commitment- allowing us to control for bank customer heterogeneity. Missing trend data prevents us from providing a long-run analysis. However, the bank-specific levels of trust and the general levels of distrust provided by the survey, together with bank customers' perceptions regarding a number of financial institutions' characteristics, distinguish our study from any previous related work.

To our knowledge, this paper is a pioneer as regards the assessment of trust in the financial system, related to bank-specific characteristics under the consideration of an underlying general level of distrust. Our analysis is interesting for two main reasons. First, it complements the existing literature that has up until now mainly focused on the determinants of general trust (Alesina and La Ferrara, 2002) and on trust in political institutions (Mishler and Rose, 2001). It also covers some holes regarding the 
determinants of trust in financial institutions developed in recent studies (Knell and Stix, 2009; Mosch and Prast, 2008). Second, this approach enables us to analyse whether the potential fall in trust is likely to be a permanent "level shift" or more likely a transitory phenomenon that will disappear once the financial crisis is over or that could be compensated through the delivery of financial services. We particularly consider if changes in trust can be associated with changes in the explanatory variables, as one can then expect the level of trust to return to its pre-crisis value when, after the end of the turbulence, the independent variables approach their normal values. If, on the other hand, our empirical model leaves the level shift in trust largely unexplained, then this can be interpreted as a "trust problem" that may indicate a permanent decline.

We specifically study two questions: What factors determine the level of trust in banks? To what extent do such factors compensate a potential loss of trust in banks due to a financial crisis? Our regressions deliver a number of interesting results. First, there are very few differences in the level of trust towards banks along socio-demographic lines (gender, age, employment situation, education, status, marital status and income). This suggests that -at least in principle- trust in banks is not confined to specific sociodemographic sub-groups of the population. Second, the perception of certain banks performance characteristics plays a much more important role than the sociodemographic characteristics.

We find the effects of bank characteristics such as the bank's sensitivity towards its customers' problems, banks' effectiveness when looking for answers to bank customers' problems, the provision of social activities and the commitment to their customers to be statistically significant across five different levels of underlying general distrust. These variables also appear to exert a symmetric impact in the sense that they are related to increases and decreases of trust in financial institutions according to the perception level.

The paper is structured as follows. In the following section, we discuss the relevant literature and provide some new evidence about the importance of trust for financial decisions. Next, we state the hypotheses by establishing the potential determinants of trust in banks. In section 4, we present our data and econometric methodology. Section 5 introduces the main results. In section 6 we include 
methodological aspects regarding the economic impact of bank customers' perceptions on trust and policy implications. Section 7 concludes.

\section{The Importance of Trust: Literature Review}

Studies from recent years consistently mention trust as a significant factor as regards economic growth, especially its great importance for financial intermediation during periods of instability. It has been suggested in several occasions that the deep distrust between banks in the course of the crisis could be inferred from the virtual breakdown of the interbank market. Guiso et al. $(2004,2008)$ support the potentially severe long-run consequences for financial markets and financial intermediation a decline of trust can have. In the short term, a further threat is the possibility of financial panics and bank runs due to the rising distrust in banks.

Trust, an important economic factor, should be considered as "a remarkably efficient lubricant to economics exchange [that] reduces complex realities far more quickly and economically than prediction, authority, or bargaining" (Powell, 1990). Moreover, according to Etzioni (1988), a level of trust is a fundamental element of the social fabric and a factor in all market transactions. Along the same lines, Sapienza and Zingales (2009) describe how: "Something important was destroyed in the last few months. It is an asset crucial to production, even if it is not made of bricks and mortar. While this asset does not enter standard national account statistics or standard economic models, it is so crucial to development that its absence-according to Nobel laureate Kenneth Arrow- is the cause of much of the economic backwardness in the world. This asset is trust".

There are many ways in which the paper relates to the literature. Many studies have analysed the relationship between trust and economic growth or other economic performance (Knack and Keefer, 1997) in the literature. It has also been suggested that the financial contracts by nature require an especially high level of trust: "While trust is

\footnotetext{
${ }^{2}$ In support of this view, the second annual Edelman Trust in US Financial Services study has shown that trust in financial services firms fell for nearly half of the surveyed individual investors in 2010. According to Edelman's research, trust in US banks has plummeted steadily since 2007. A similar study from Forrester in early 2010 concluded that roughly $70 \%$ of big bank customers do not trust their banks. Similarly, a Harris poll found that bank reputations have suffered, as few Americans find statements by financial institutions believable.
} 
fundamental to all trade and investment, it is particularly important in financial markets, where people depart with their money in exchange for promises. Promises that aren't worth the paper they're written on if there is no trust" (Sapienza and Zingales, 2009). In agreement with this argument, some papers have demonstrated that trust is positively correlated with access to credit, the use of checks, lower interest rate margins, stock market capitalisation, households investments in stocks and deeper and more efficient financial markets in general (e.g. Porta et al. 1997, Calderon et al. 2002, Guiso et al.2004 and Guiso et al. 2008). More recently, Sapienza and Zingales (2009) showed that the level of trust in banks and the likelihood of deposit withdrawals by U.S. citizens are related.

Most of this literature has in fact focused on the "general trust question" (i.e. trust in other people) and there is less research that has focused categorically on institutional trust, in particular, trust in financial institutions. An example of some literature on trust in political institutions includes Mishler and Rose (2001), and the determinants of trust in various other institutions have been studied: e.g. in Hudson (2006), Torgler (2007), Fischer and Hahn (2008), Mosch and Prast (2008) or Gros and Roth (2009). There are also a number of papers that investigate the evolution of trust and confidence and the interaction of general and institutional trust with government regulation (Carlin et al., 2009 and Aghion et al., 2009).

There are two alternative, although probably complementary, explanations for the determination of institutional trust. Cultural theories argue that it is exogenous (Inglehart, 1997) and based on dyadic trust. As such, it is frequently viewed as being learned early in life. Institutional theories, on the other hand, argue that it is endogenous (Hetherington, 1998 and North, 1990) and influenced by institutional performance. Newton (1999) also concludes that dyadic and political trust, a component of institutional trust, are conceptually distinct. The first suggests that there should be relatively little difference in the levels of trust in different institutions and it is not obvious why it should vary with factors such as age, marital status or state change variables, although it may be linked to other socio-economic variables such as gender and education which might reflect differences in the socialization process. In addition, to the extent that people do not move geographically and the relative income of the parents is passed to the children then it might also be expected an impact of income and location on trust. However, trust may also differ from person to person with some 
people being "naturally trusting" in both dyadic and holistic contexts, and these results in them tending to trust all institutions more than other people.

Mishler and Rose (2001) analyse institutional trust in Central and Eastern Europe along several dimensions including parliament, trade unions, the police, the courts and the media. Using regression analysis they analyse trust in institutions as a whole, defined as average trust in six institutions. The results show only a weak significance for socio-economic variables, with trust increasing with age and for smaller towns and villages. Perceptions of factors such as corruption and economic performance are in contrast much more significant. They also find little evidence that dyadic trust impacts on political trust. Brewer et al. (2004) conclude that in the USA trust in other nations is dependent upon social trust, domestic political trust and declines with age. Schweer (1997) focuses on the determinants of young adults' experienced trust towards the central institutions of society and concludes that the perceived attributes of an institution are relevant for the degree of experienced trust. Williams et al. (1999) analyse trust amongst residents close to a nuclear weapons site in the USA and conclude it is influenced by a variety of factors including personal traits, experiences and economic needs.

Three articles are however very closely related to our study, in the sense that they specifically analyse trust in financial institutions. In the first place, Knell and Stix (2009) study whether trust in Austrian banks has declined during the global financial crisis and assess what factors determine the level of trust in Banks. The authors provide evidence that the degree of individual information does not influence trust, that banking trust is contagious and that the extension of deposit insurance coverage in October 2008 had a positive effect on trust. The authors also show that trust in banks is mainly affected by "subjective" variables like the individuals' assessment of the current economic and financial situation and by their future outlooks. Among their central "subjective" variables, the authors consider several proxies related to the financial situation of the household, bank customers' perception of their own and the economic future, and the perception of inflation and Euro currency stability.

In the second place, Mosch and Prast (2008) provide evidence regarding trust in banks for the Dutch financial sector. Based on surveys over the period 2003-2006, the authors find a significant positive link between confidence in the economy and trust in 
the country's institutions, in line with the results provided by Knell and Stix (2009). In the third place, Gill et al. (2006) studied the impact of some personal level features related to the provision of banking services to customers such as empathy, kindness and similarity or affinity, and others related to the actual provision of bank services such as customization, competition and management. The results suggest that the six factors generally favor confidence, and the authors suggest that the weight of the factors varies during different periods established during the bank-customer relationship.

Our contribution to the literature is two-fold. On one side, we analyse the extent to which bank customers' perceptions of several bank attributes, controlling for demographic and more general "subjective" variables, and foster trust in financial institutions. Second, we study in what degree can a potential loss of trust in banks due to a financial crisis be offset by bank customers’ perceptions of such attributes.

\section{The Determinants of Trust in Banks}

It is not oblivious to conciliate the bank relationship theoretical background with the development of a theoretical framework for trust in banks. We can define a bank relationship as the association between a bank and customer that goes beyond the execution of simple, anonymous, financial transactions. According to the literature on relationship banking, it is unclear how important a close relationship between bank and customer actually is (Ongena and Smith, 1998).

However, there are potential benefits of such relationship, for example, the transfer of proprietary information or a commitment to continue to do business together through times of financially difficulty, among others. The authors argue that "the global trends towards deregulation, disintermediation and securitisation appear to only accelerate the transition from relationship-intensive services to more market or transactions-oriented financial products. Yet relationship-intensive financing may be a fundamental ingredient in the nurturing of developing firms and economies".

A given banks' ability to maintain a relationship depends on the quality and price of services offered, the quality of the customer and the competitive environment in which the bank operates. In this way, considering that a bank provides a customer with a multitude of services over time, it is able to learn a great deal about the financial needs 
of its customers, allowing the bank to tailor its services to suit their financial requirements, encouraging an affinity between them, and therefore making the customer willing to demand its financial services from the bank it trusts. This framework becomes especially useful when setting up our analyses of the determinants of financial trust. $^{3}$

Deduced from a sociological perspective, Zucker (1986) characterizes three central mechanisms of "trust production" in economic structures; process-based, characteristic-based, and institutional-based trust. ${ }^{4}$ In the process-based mode, trust arises either through the personal experience of recurring exchanges or from expectations based on reputation. If a long-term balance emerges, such repeated exchanges create a system of diffused social norms of mutual obligation and expectations of equitable treatment (Zucker, 1986). Through this process, transactions become embedded in a social context where the personal overlaps the economic (Braddach and Eccles, 1989; Granovetter, 1985, 1992). The security and stability of such recurring reciprocal exchanges enable learning and engender trust (Powell, 1990). According to Bromiley and Cummings (1992), people trust those who have interacted sincerely with them in the past. This suggests that hypotheses can be developed concerning the impact of differing economic systems and performance characteristics, on the development of individuals' predispositions to trust or distrust.

Trust is a crucial variable that concerns our relationships with all those that we interact with. Trust works on the belief that the other person, organisation or institution will consider the interests of all concerned, and to trust in an institution, a person would need to be confident that things will be carried out to a satisfactory level. Reputation based on past behaviour becomes an important factor regarding trust between people and institutions, as does future expectation, as individuals are reluctant to allow others to influence their welfare if they are uncertain about the potential harm that may be caused. Indeed, Sobel (2002) defines trust as the willingness to permit the decisions of others to influence individual's welfare.

\footnotetext{
${ }^{3}$ As an example, most surveyed individuals in the second annual Edelman Trust in U.S. Financial Services study cited "honest communication" and "transparency" as keys to reputation and trust.

${ }^{4}$ Although these categories stem from a sociological perspective, there are clear commonalities with economics.
} 
In choosing the set of independent variables we go back to the literature on dyadic and holistic trust (Hudson, 2006). As stated by Hudson (2006) individuals consider the extent they trust the institution to fulfil its role in a satisfactory manner. Accordingly, it appears likely that individual $i$ will trust the institution $h$ provided the perceived probability that they will carry out their remit to a satisfactory degree. Our paper considers this factor in a different way. Since our data includes information on bank customer general level of distrust as well as the perception of several bank performance variables, we control for heterogeneity in trust in banks by using this information.

A controversial issue in this literature is whether institutional trust is simply a function of an individual's level of general trust or whether it is influenced by institutional performance. Without taking a stance on this issue we include explanatory variables that are related to both theoretical approaches. First, we take the usual set of socio-demographic variables that have been shown to have some explanatory power in specifications involving general trust (Alesina and La Ferrara 2002, Rainer and Siedler 2009). These include variables such as age, gender, employment situation, education, marital situation, etc. It should be noted that these and other socio-demographic characteristics might not only influence general trust, but also the probability and the type of contact with financial institutions and the ability to assess the quality of bank's accomplishments. This might be an important factor if institutional trust is related to the (actual or perceived) performance of the institution.

Following these considerations, we also include a set of additional variables that might directly influence a person's attitude towards banks and also their ability to judge their past and present performance. Hence, in addition to the socio-demographic variables we also use a number of variables that are related to bank customers' perception of several characteristics and attributes of their own bank; i.e. sensitivity, efficiency, service, social activities, comfort and commitment. Whatever the rationale for their influence, the existing literature has often shown that these subjective variables are important determinants of trust (Rainer and Siedler, 2009). ${ }^{5}$ Trust could be then

\footnotetext{
${ }^{5}$ We want to stress, however, that the use of perception variables makes it almost impossible to pin down causality in a satisfactory manner. Trust and other personal attitudes and views are formed in a simultaneous way. We therefore regard our analysis as determining systematic relation between these subjective variables rather than attempting to provide evidence on causal mechanisms.
} 
usefully conceived as a function, with the amount of trust varying as the result of some combination of characteristic similarity and positive relational experience, with broad societal norms and expectations setting a baseline or intercept -the initial expectations of general trustworthiness-.

\section{Data and Methodology}

\subsection{Data}

Our dataset is the 2009 survey conducted by the "Instituto de Encuestas y Opinión Pública" (IMOP) on trust in financial institutions in Spain. The survey is based on a broad sample size of 1,601 bank customers covering the entire Spanish territory. The survey was carried out by computer-aided telephone interviews using the CATIPTM (own produced CATI for PC network) computer-assisted telephone survey technique. The sample error in the case of $\mathrm{p}=\mathrm{q}=50 \%$, for a $95.5 \%$ confidence level, was $+1.8 \%$. The field work was carried out in January 2009 by a team of IMOP telephone field network interviewers. The survey sample is nationally representative, and it contains rich information about bank customers' perception of several bank attributes, which is usually not available in other data sources. Key features of our data are as follows.

First, our data set includes information on the underlying level of general trust. This allows us to examine whether the level of specific trust in banks is different according to differences in the general level of trust. Second, in addition to individual demographic characteristics, the survey asked each respondent to provide his/her perceptions towards several bank attributes. Typically, bank customers' perceptions are not easily observed, or they are rarely incorporated for econometric analyses. We will argue that this type of data allows us to control for the unobserved bank customer heterogeneity that could lead to severe bias in estimates of the effect of bank customers' perception of different bank characteristics.

Second, the survey asked about the specific level of trust in banks by type of financial institution, including commercial banks and savings banks. A respondent chooses one out of six levels of specific trust in banks -strongly agree, agree, neither agree nor disagree, disagree, strongly disagree and don't know. We interpret the level of 
agreement as the customer specific level of trust in banks when estimating an individual level discrete choice model.

Third, the survey asked respondents if they believe Spanish financial institutions are changing their behaviour as a consequence of the current crisis for better or worse by type of financial institution. We assume that the specific level of trust in a bank belongs to a customer's choice set in a particular financial institution according to his/her belief regarding whether the different types of financial institutions have changed their behaviour with the crisis. This allows us to control for consumer heterogeneity of choice set, which could also lead to bias in parameter estimates. Summary statistics for this sample are shown in Table 1.

\subsection{The Econometric Set-Up}

This section discusses our estimation approach and our econometric model specifications. We estimate two specifications of a multinomial logit model that explains the specific level of trust in financial institutions chosen by bank customers employing several variables that allow the identification of the bank-customer relationship background. ${ }^{6}$ The specific level of trust in banks (trust_fin) is proxied by the question: "I trust the solvency of commercial banks/savings banks in general and of my commercial bank/savings bank in particular". The general level of individual distrust (distrust) is measured by the question: "I generally distrust people I do not have a close relationship with". The variables that identify bank-customer relationship aspects are proxied by several questions related to bank customers' perceptions regarding banks' sensitivity (sensitive), efficiency (effic), service (service), social activities (social_act), comfort (comfort) and commitment (commit). The variables trust_fin, distrust, sensitive, effic, service, social_act, comfort and commit are measured by a $0-5$ scale.

In what follows, we discuss the specification of the model by assuming a typical situation faced by econometricians, where the data on bank customer perceptions

\footnotetext{
${ }^{6}$ As there are six response categories related to the level of specific trust in a financial institution that consist of "strongly agree", "agree", "neither agree nor disagree", "disagree", "strongly disagree" and "do not know", and the category "do not know" invalidates models for ordinal outcomes, we perform a multinomial logit model (MNLM) which is the most frequently used nominal regression model in such cases. Although there might be a potential loss of efficiency in using this model, such loss is counteracted by avoiding potential bias.
} 
toward each specific level of trust in a bank were not available. This specification will help us explain the endogeneity problem of the general level of trust. We assume that the specific level of trust of bank customer $i$ in a financial institution $h$, with an underlying level of general of distrust $j$, is defined as follows:

$$
\text { trust_fin }_{i j h}=\alpha_{j h}+X_{i} \beta_{j h}+\text { distrust }_{i j} \delta_{j h}+\varepsilon_{i j h}+e_{i j h}
$$

where $X_{i}$ is a vector of bank customer characteristics; distrust ${ }_{i j}$ is a vector of general level of distrust related dummies; $\varepsilon_{i j h}$ captures the unobserved bank customer perception of general distrust $j$ at financial institution $h$; and $e_{i j h}$ captures de measurement errors and it is assumed to be i.i.d. $\alpha_{j h}$ measures the mean level of specific trust in a financial institution under a general level of distrust $j$ at financial institution $h$, regardless of consumer characteristics. $\beta$ and $\delta$ are vectors of the specific level of trust in a financial institution for $X_{i}$ and distrust $_{i j}$, respectively. In particular, $\delta$ captures the direct effect of general level of distrust dummies -it measures the immediate impact of the underlying level of distrust on the specific level of trust in a financial institution.

If distrust ${ }_{i j}$ is uncorrelated with $\varepsilon_{\mathrm{ijh}}$, one can estimate this specification using a multinomial logit model and obtain consistent estimates on the general level of distrust dummies. However, it is likely the dummies for the general level of distrust might be positively correlated with $\varepsilon_{\mathrm{ijh}}$. To handle this potential positive correlation, our approach here is to use the data on banks customer perception toward several banks' attributes as a proxy for $\varepsilon_{\mathrm{ijh}}$. The idea is that if we control for $\varepsilon_{\mathrm{ijh}}$, then it is possible to obtain consistent estimates of the effect of the general level of distrust. ${ }^{7,8}$ As for the attitudinal data, we use the six consumer perceived attributes of financial institutions previously mentioned: sensitive, effic, service, social_act, comfort, commit. It is important to note that this type of attitudinal data is not typically observed and all of them are subjective measures reported by individual bank customers. In particular, the second feature suggests that our attitudinal data could potentially capture a significant amount of bank customer heterogeneity in the specific level of trust in a financial

\footnotetext{
${ }^{7}$ We do not assume a priori that the attitudinal data are a good proxy for individual specific levels of trust in financial institutions. Instead, we let the estimated model tell us whether the attitudinal data are informative or not.

${ }^{8}$ As pointed out by Harris and Keane (1999) and Keane (2004), using attitudinal data to control for unobserved heterogeneity provides an alternative to the conventional econometric approach of using instrumental variables. But, unlike instrumental variables, this approach works in non-linear models, such as the multinomial logit model considered here.
} 
institution. In the full specification of our model, the specific level of trust of bank customer $i$ in a financial institution $h$, with an underlying level of general of distrust $j$, is defined as follows:

$$
\text { trust_fin }_{i j h}=\alpha_{j h}+X_{i} \beta_{j h}+\text { distrust }_{i j} \delta_{j h}+Z_{i j} Y_{h}+e_{i j h}
$$

where $Z_{i j}$ is a vector of attributes under the general level of distrust $j$ evaluated by bank customer $i .^{9}$

\section{Results}

\subsection{Estimation of the baseline model}

Coefficients of bank customer socio-demographic characteristics are presented in column 1 of Table 3a. The results are generally aligned with findings of previous studies. The variable income appears to be the most crucial characteristic of bank customers, and it is statistically significant across all levels of trust in banks, while other characteristics, such as married or age are statistically significant for only a few levels of trust in banks. ${ }^{10}$

Column 2 of Table $3 \mathrm{a}$ reports coefficients for the variables regarding bank customers' perceptions of most of banks' attributes. It can be noted that bank customers' perceptions of most of banks' attributes measuring institutional performance or quality tend to have a positive effect regarding trust in banks (some of them presenting almost a symmetrical impact considering the base outcome). For this specification, most of the perception variables have expected signs and are highly statistically significant across the different levels of trust in banks. Overall, sensitive and effic seem to be the most crucial perception variables. More specifically, for one unit change in the variable sensitive, the $\log$ of the ratio of the two probabilities, $\mathrm{P}($ trust_fin=4)/P(trust_fin=2), will be increased by 0.81 . Therefore, we can say that, in general, the more a person values their bank's sensitivity to bank customers’ problems,

\footnotetext{
${ }^{9}$ The approach is equivalent to assigning a level of indirect utility to each alternative and assuming that individuals choose the alternative that yields the greatest utility. Indirect utility is assumed to be a function of economic and demographic variables as well as other unobserved characteristics. Coefficient estimates represent the differential effects of the observed characteristics on utility.

${ }^{10}$ The log-likelihood ratios confirm that including attitudinal data in our analysis improves the fit of our model significantly, as it improves the log-likelihood from-1,970.19 to -1,741.55.
} 
the more they will tend to trust. Similarly, for one unit change in the variable effic, the $\log$ of the ratio of the two probabilities $\mathrm{P}($ trust_fin=4)/P(trust_fin=2) will increase by 0.453. It can then be understood that as the perception that bank customers have regarding the effectiveness of banks when looking for answers to bank customers' problems increases, the level of trust is enhanced.

Similar results are obtained for other perception variables such as social_act and comfort, as the variables social_act and comfort are significant regarding their effect on higher levels of trust, i.e. trust_fin $=4$. However, their coefficients are not statistically significant for other levels of trust in banks. It appears that for one unit change in the variable social_act, the log of the ratio of the two probabilities $\mathrm{P}($ trust_fin=4)/P(trust_fin=2) will be increased by 0.627 , implying that the execution of social activities by banks has a positive effect on trust in banks. Moreover, the results reflect that the more comfortable bank customers feel when they visit their bank (comfort), the more they trust their bank (the log of the ratio of the two probabilities $\mathrm{P}($ trust_fin=4)/P(trust_fin=2) will be increased by 0.756$)$.

Column 3 of Table 3a presents the coefficients for the complete baseline model. Interestingly, including bank customer characteristics as control variables does not seem to alter the significance and impact of coefficients for perception. The perception variables hold expected signs and are highly statistically significant across the different levels of trust in banks.

\subsection{Marginal effects of the baseline model}

Although the intuition provided above offers a first analytical approach, the use of probability models for multiple responses lends itself to the interpretation of parameters in terms of marginal probability effects. In order to interpret the results appropriately the multinomial logit results are presented in terms of marginal effects,

which are computed as $\frac{\partial \operatorname{Pr}\left(\text { trust_fin }_{i}=j \mid z\right)}{\partial z_{i}}$ where $\operatorname{Pr}\left(\right.$ trust_fin $\left._{i}=j \mid z\right)$ is the probability of trusting a financial institution to a certain level given the changes observed in variable $z_{i}{ }^{11}$ The question of interest is: How does the probability of

\footnotetext{
${ }^{11}$ The marginal effects for one variable are estimated holding the rest of the variables constant at their mean values.
} 
observing a certain outcome $j=1, \ldots, J$ change if, ceteris paribus, one of the explanatory variables changes? In this paper, we are mainly interested in the effect of a change in bank customers' perception of several bank attributes on the probability of trust in banks. To get a feel for the economic significance of this effect, we calculate the impact of marginally increasing bank customers' perception of several bank attributes on the probability of trusting a bank with the mean values for all the other variables. In what follows, we report the marginal effects at the mean of the independent variable trust_fin, as offered by Table 3b.

All coefficients related to bank customers' perceptions of bank attributes and characteristics appear to be significantly positive for positive outcomes of trust in banks, and significantly negative for negative outcomes regarding trust in banks, following an almost harmonic effect along the outcome distribution. As expected, ceteris paribus, the perception of a bank's sensitivity towards bank customers' problems (variable sensitive) is found to be positively and significantly related to positive levels of trust in banks (5.63\% considering trust_fin=3 and $4.88 \%$ for trust_fin=4), while simultaneously related negatively and significantly to negative levels of trust in banks (-6.04\% for trust_fin $=1$ and $-3.43 \%$ considering trust_fin=0).

Similarly, banks' effectiveness when looking for answers to their customers' problems (variable effic) also fosters the probability of trust in financial institutions, along both sides of the outcome distribution. Other customer perceptions of bank attributes and characteristics appear to affect trust in banks in a similar fashion. In this sense, a marginal increase in the perception of the quality of the services provided by a bank (variable service) -compared to other nearby institutions- has a positive and significant impact on the probability of trust in banks of $2.24 \%$ at its highest outcome level (trust_fin=4). Moreover, social activities delivered by banks in general and the customer's bank in particular(variable social_act) and the perceived comfort when visiting their bank (variable comfort) are found to be positively and significantly related to the probability of trust in banks at its highest outcome level(trust_fin=0) with the marginal effects being $3.96 \%$ and $5.39 \%$, respectively. Such perceptions are also negatively and significantly related to the probability of trust in banks at its lowest outcome level (trust_fin=0) with the marginal effects being $-1.59 \%$ and $-1.28 \%$, respectively. 
Among demographic characteristics, the variable gender appears to have a significant impact on the level of trust in banks. Being a woman has a negative average marginal effect of $-7.43 \%$ regarding the outcome level trust_fin=3 and a positive average marginal effect of $4.4 \%$ regarding the outcome level trust_fin=1. Similarly, the employment situation of the respondent (variable employ_situ) is positively and significantly related to the probability of trust in banks. In particular, bank customers that are currently working present a positive marginal effect of $1.73 \%$ regarding the highest outcome level (trust_fin=4). Finally, the variable married has a significant effect on the level of trust in banks. Being married has a negative average marginal effect of $-1.91 \%$ regarding the outcome level trust_fin $=3$ and a positive average marginal effect of $1.51 \%$ regarding the outcome level trust_fin $=1$. Other demographic variables, such as the age of the respondent, the level of education, the perceived status and the level of income do not appear to have impact the level of trust in banks.

\subsection{Estimation of trust in banks by levels of distrust}

Table $4 \mathrm{a}$ and Table $4 \mathrm{~b}$ present coefficients for dummies related to the general level of distrust (distrust). ${ }^{12}$ The results are consistent with our endogeneity arguments discussed in the previous section. It should be emphasised that after controlling for the different levels of distrust, bank customer perception variables tend to remain statistically significant. Although most independent variables loose explanatory power under distrust $=3$ and distrust $=4$, it seems reasonable that the effect of bank customers' perceptions on trust in financial institutions loses significance for higher levels of general distrust.

The variables service and comfort seem to be the most crucial perception variables when considering a neutral general level of distrust (distrust=2). In such case, for one unit change in the variable service, the log of the ratio of the two probabilities, $\mathrm{P}($ trust_fin=4)/P(trust_fin=2), will be increased by 4.863 . Therefore, we can say that, in general, the better services a bank provides compared to other nearby institutions, the more bank customers will tend to trust in such financial institution. Similarly, for one unit change in the variable comfort, the $\log$ of the ratio of the two probabilities

\footnotetext{
${ }^{12}$ In what follows, demographic variables are omitted as we focus our analysis on variables related to bank customers' perceptions of bank attributes and characteristics. In support of this analysis, Table 4c and Table $4 \mathrm{~d}$ present marginal effects for different levels of general distrust (distrust).
} 
$\mathrm{P}($ trust_fin=4)/P(trust_fin=2) will increase by 5.272. It can then be understood that the more comfortable a customer feels when visiting their bank, the higher the level of trust in the bank. Similar results are obtained for other perception variables such as sensitive and social_act, although these are not as significant. Interestingly, considering a neutral underlying level of distrust, the variable commit appears to have a positive effect on trust in banks, as increasing commit by one unit, the $\log$ of the ratio of the two probabilities $\mathrm{P}($ trust_fin=0)/P(trust_fin=2) will be decreased by -1.680 , implying that by meeting its commitments with its customers a bank reduces the probability of experiencing a drop in trust.

Moreover, under lower levels of distrust (i.e. distrust $=0$ and distrust $=1$ )the results reflect that the more comfortable bank customers feel when they visit their bank (comfort), the higher sensitivity banks show towards their customers' problems (sensitive) and the better services banks provide (service), the more customers trust their bank. Overall, we interpret this as evidence that bank customers' perception of bank attributes increases customers' likelihood of trusting the bank they operate with, i.e., the direct effect of perception variables is present.

\subsection{Estimation of trust in banks by type of financial institution}

Table 5a presents the coefficients of perception variables by type of financial institution (commercial banks or savings banks). ${ }^{13}$ In general, coefficients appear to have a greater impact and to be economically more significant in the case of savings banks. This could probably be due to the traditional values extended by savings banks in Spain and their proximity and relational banking activity.

The variable sensitive appears to be the most decisive perception characteristic when explaining customers' trust in banks, and it is statistically significant across most levels of trust in banks. More specifically, for one unit change in the variable sensitive, the $\log$ of the ratio of the two probabilities, $\mathrm{P}($ trust_fin=4)/P(trust_fin=2), will be increased by 0.836 in the case of commercial banks and 0.867 in the case of savings banks, both at the 1 per cent level. Hence, the more a customer values their bank's sensitivity to their problems, the more they will tend to trust in their bank, with a higher impact in the case of savings banks. Similarly, for one unit change in the variable

\footnotetext{
${ }^{13}$ Supporting these results, Table 5 presents marginal effects by type of financial institution (commercial banks or savings banks).
} 
sensitive, the $\log$ of the ratio of the two probabilities $\mathrm{P}($ trust_fin $=0) / \mathrm{P}($ trust_fin=2) will decrease by -0.786 in the case of commercial banks and by -0.812 in the case of savings banks.

The variable comfort is statistically significant only regarding the level of trust in banks as defined by trust_fin=4, and it appears to be considerably more significant in the case of savings banks. Increases in the perception that bank customers have regarding how comfortable they feel when they visit their bank foster their level of trust in banks (for one unit change in the variable comfort, the log of the ratio of the two probabilities $\mathrm{P}($ trust_fin=4)/P(trust_fin=2) will increase by 0.580 in the case of commercial banks and by 0.809 in the case of savings banks).

Likewise, the variable social_act is statistically significant only regarding the level of trust in banks as defined by trus_fin=4, and it is more significant in the case of savings banks. Increases in the value given to social activities by bank customers enhance trust in banks (for one unit change in the variable social_act, the log of the ratio of the two probabilities $\mathrm{P}($ trust_fin=4)/P(trust_fin=2) will increase by 0.515 in the case of commercial banks and by 0.8 in the case of savings banks).

\subsection{Robustness of the Estimates}

As robustness checks, we perform a likelihood-ratio test and a Wald test. Formally, regarding the likelihood-ratio test the hypothesis that all coefficients associated with trust_fin are simultaneously equal to 0 can be rejected at the 0.1 level $(d f=5, p<0.01)$. The Wald test offers the same results (the hypothesis that all coefficients associated with trust_fin are simultaneously equal to 0 can be rejected at the 0.1 level). Moreover, we study the case of multiple independent variables. We test the effects of two or more independent variables being simultaneously equal to 0 , rejecting all hypotheses at the 0.1 level.

Furthermore, we test for the independence of irrelevant alternatives (IIA). Specifically we perform a Hausman test of IIA and Small-Hsiao test of IIA. Due to the ambiguity of the results provided by the Hausman test, we focus in the Small-Hsiao test. 
According to the latter IIA hold in all cases, meaning that adding or deleting alternatives does not affect the odds among the remaining alternatives. ${ }^{14}$

\section{Policy Implications: Rebuilding trust}

We now discuss the results from our policy implications: what would be the effect of variations in bank customers' perceptions towards bank attributes on trust in banks? Note that this experiment only affects bank customers who currently consider that Spanish financial institutions are changing their behaviour for the worse. We divide this sub-sample of customers into five groups according to their levels of general distrust: (i) distrust=0, (ii) distrust=1, (iii) distrust=2, (iv) distrust=3 and (v) distrust=4. For every group, we calculate the marginal effects of each independent variable on the level of trust in banks, holding the others constant at their mean.Tables6 to 11 show the marginal effects of variations in bank customers' perception variables considering five different levels of general distrust, including consumers' different levels of general distrust by rows, assigning four alternative probabilities of trust in banks to each of them by columns.

Focusing on the most relevant results, the marginal effects of changes in customers' perception as defined by sensitive are included in Table 6. For all levels of general distrust customers would increase their probabilities of trusting their bank considering a unit change in sensitive. Most interestingly, for customers with a neutral level of general distrust the increase of trust in banks (from neither agreeing nor disagreeing on trusting to agreeing on trusting banks) would be of $34.7 \%$.Similarly, Table 11 presents the approximation for the amount of change in trust in banks that will be produced by a unit change in commit. It appears that for customers with a neutral level of general distrust the increase of trust in banks (from neither agreeing nor disagreeing on trusting to agreeing on trusting banks) would be of $34 \%$.

Overall, although in some cases changes in probability of trust in banks vary across the different levels of general distrust, their magnitudes are moderate and in most cases intuitive. Assuming that bank customers who consider that Spanish financial institutions

\footnotetext{
${ }^{14}$ We also obtain robust results according to the likelihood-ratio and Wald tests for combining alternatives. Results are available upon request.
} 
are changing their behaviour for the worse would likely tend not to trust in banks, our results indicate that for the majority of the policy implications, such a potential loss of trust in banks due to the financial crisis is offset by the perceptions of such bank attributes.

\section{Conclusions}

In this article we examine bank customers' trust in Spanish banks, based on unique survey evidence. Our data provide information about the specific level of trust in banks -proxied by the level of bank customers' trust in the solvency of commercial banks/savings banks in general, and of their own commercial bank/savings bank in particular, about the general level of individual distrust -measured by the level of bank customers' distrust in people they do not have a close relationship with- and about the perception that bank customers' have regarding several characteristics and attributes of their own bank.

We present evidence consistent with the fact that bank customer perception of several bank-specific characteristics impact the level of trust in banks. Controlling for bank customer heterogeneity, we find the effects of bank customers' perception of several bank attributes to be statistically significant. Most importantly, we find evidence that shows that bank's sensitivity towards its customers' problems is positively related to the level of trust in the bank. This same trend also appears to be acquainted by variables such as banks' effectiveness when looking for answers to bank customers' problems, the provision of social activities and commitment to their customers.

We are also concerned with analysing the fact that in general socio-demographic characteristics do not appear to have an effect on the level of trust in Spanish financial institutions. Our results also show that including bank customers' perception of several bank attributes produces a substantial improvement in model fit and allows us to alleviate the endogeneity problem of general trust. This highlights the importance of collecting this type of data in order to lessen the potential omitted variable bias when conducting surveys to study bank customers' trust in financial institutions.

We provide the first effort to understand how bank customers' perceptions affect trust in financial institutions. It could be that the process of restoring trust with the 
public might have to start within banks. Our policy implications suggest that for the sub-population of bank customers with neutral levels of general distrust, who also consider that Spanish financial institutions are changing their behaviour for the worse, an increase in banks' sensitivity towards customers' problems and banks' commitment to their customers would increase their probability of trusting banks by $34.7 \%$ and $34 \%$, respectively.

Although we believe that our paper provides some useful information for the current policy debate on how to restore trust in banks, there are still many unanswered questions due to data limitations. Collecting more information on customers' perception of bank attributes is crucial to further improve our understanding about how such bank characteristics affect the development of trust. Another limitation of our study is that our sample does not provide a trend data to develop a long-run analysis. Yet, several questions remain unanswered. How does customers' perception of bank attributes affect trust in financial institutions over time? How would customers' perception of bank characteristics and trust in banks impact in de demand of financial services and products? We leave these important questions for future research.

\section{References}

Aghion, P., Algan Y., Cahuc P., and Shleifer A., 2009. Regulation and Distrust. NBER Working Papers 14648, National Bureau of Economic Research, Inc.

Alesina, A. and La Ferrara E., 2002. Who Trusts Others? Journal of Public Economics 85(2), 207-234.

Braddach, J. L. and Eccles, R. G., 1989.Price, authority and trust: From ideal types to plural forms. Annual Review of Sociology, 15, 97-118.

Brewer, P. R., Gross K., Aday S. and Willnat L., 2004. International Trust and Public Opinion about World Affairs. American Journal of Political Science, 48, 93109.

Bromiley, P. and Cummings, L.L., 1992. Transactions cost in organizations with trust. Discussion Paper 128, Minneapolis: University of Minnesota, Strategic Management Research Center. 
Calderon, C., Chong, A. and Galindo, A.,2002.Development and Efficiency of the Financial Sector and Links with Trust: Cross-Country Evidence. Economic Development and Cultural Change, 51(1), 189-204.

Carlin, B. I., Dorobantu, F. and Viswanathan, S., 2009.Public Trust, the Law, and Financial Investment. Journal of Financial Economics, 92(3), 321-341.

Etzioni, A., 1988. The moral dimension: Toward a new economics. New York: Free Press.

Fischer, J. A. and Hahn, V., 2008. Determinants of Trust in the European Central Bank. Working Paper Series in Economics and Finance 695, Stockholm School of Economics.

Gill, A. S., Flaschner, A. B. and Shachar, M., 2006. Factors that affect the trust of business clients in their banks, International Journal of Bank Marketing, 24(6), 384-405.

Granovetter, M., 1985. Economic action and social structure: The problem of embeddedness. American Journal of Sociology, 91(3), 481-510.

Granovetter, M., 1992. Economic institutions and social constructions: A framework for analysis. Acta Sociológica, 35, 3-11.

Gros, D. and Roth, F., 2009. The Crisis and Citizens' Trust in Central Banks. Available online at: http://www.voxeu.org/index.php?q=node/3943.

Guiso, L., Sapienza, P. and Zingales, L., 2004. The Role of Social Capital in Financial Development, American Economic Review, 94(3), 526-556.

Guiso, L., Sapienza, P. and Zingales, L., 2008. Trusting the Stock Market, The Journal of Finance, 63(6), 2557-2600.

Harris, K., Keane, M.P., 1999. A model of health plan choice: inferring preferences and perceptions from a combination of revealed preference and attitudinal data. Journal of Econometrics 89, 131-157.

Hetherington, M. J., 1998. The Political Relevance of Political Trust. American Political Science Review, 92: 791-808. 
Hudson, J., 2006.Institutional Trust and Subjective Well-Being across the EU. Kyklos, 59(1), 43-62.

Inglehart, R., 1997. Modernization and Postmodernization, Cultural Economic and Political Change in 41 Societies, Princeton: Princeton University Press.

Keane, M.P., 2004. Modelling health insurance choice using the heterogeneous logit model. Working paper, Department of Economics, Yale University.

Knack, S. and Keefer, P., 1997. Does Social Capital Have an Economic Payoff? A Cross-Country Investigation. The Quarterly Journal of Economics, 112(4), 12511288.

Knell, M. and Stix, H., 2009. Trust in Banks? Evidence from normal times and from times of crises. Oesterreichische Nationalbank, Working Paper, 158.

Mishler, W. and Rose, R., 2001.What Are the Origins of Political Trust? Testing Institutional and Cultural Theories in Post-communist Societies. Comparative Political Studies, 34(1), 30-62.

Mosch, R. and Prast, H., 2008. Confidence and Trust: Empirical Investigations for the Netherlands and the Financial Sector. Forthcoming in The Quarterly Journal of Economics.

Newton, K., 1999. Social and Political Trust in Established Democracies. In "Critical Citizens: Global Support for Democratic Governance". Oxford University Press, $169-187$.

North, D.C., 1990. Institutions, Institutional Change and Economic Performance. New York: Cambridge University Press.

Ongena, S. and Smith, D.C., 1998.Bank Relationships: A Review. In "The Performance of Financial Institutions”. Cambridge University Press.

Porta, R.L., Lopez-de Silanes, F., Shleifer, A. and Vishny, R.W., 1997. Trust in Large Organizations. The American Economic Review, 87(2), 333-338.

Powell, W.W., 1990. Neither market nor hierarchy: Network forms of organization. In "Research in organizational behaviour". Greenwich, CT: JAI, 12, 295-336, 
Rainer, H. and Siedler, T., 2009. Does Democracy Foster Trust?. Journal of Comparative Economics, 37(2), 251-269.

Sapienza, P. and Zingales, L., 2009. A Trust Crisis. Available online at: http://faculty.chicagobooth.edu/brian.barry/igm/atrustcrisis.pdf.

Sobell, J., 2002. Can we trust social capital? Journal of Economic Literature, 40, 139154.

Schweer, M.K.W., 1997. Trust in Central Social Institutions: Results of an Empirical Study of Young Adults. Gruppendynamik-Zeitschrift Fur Angewandte Sozialpsychologies, 28, 201-210.

Torgler, B., 2007. Trust in International Organizations: An Empirical Investigation Focusing on the United Nations. School of Economics and Finance Discussion Papers and Working Papers Series, 213.

Williams, B.L., Brown S. and Greenberg M.,1999. Determinants of Trust Perceptions among Residents Surrounding the Savannah River Nuclear Weapons Site. Environment and Behaviour, 31, 354-371.

Zucker, L.G., 1986. Production of trust: Institutional sources of economics structure. In "Research in organizational behaviour". Greenwich, CT: JAI, 53-111. 
Table 1

Summary statistics.

\begin{tabular}{|c|c|c|c|c|c|}
\hline Variable & No. of Obs. & Mean & Std. Dev. & Min & $\operatorname{Max}$ \\
\hline trust_fin & 1601 & 2.72 & 1.12 & 0 & 5 \\
\hline gender & 1601 & 0.50 & 0.50 & 0 & 1 \\
\hline age & 1601 & 43.00 & 11.18 & 25 & 65 \\
\hline employ_situ & 1601 & 4.11 & 1.38 & 0 & 5 \\
\hline educat & 1601 & 1.90 & 0.82 & 0 & 3 \\
\hline status & 1601 & 2.29 & 0.98 & 0 & 4 \\
\hline married & 1601 & 1.12 & 1.65 & 0 & 5 \\
\hline income & 1601 & 3.00 & 1.26 & 0 & 6 \\
\hline mfi_oper & 1601 & 0.73 & 0.52 & 0 & 2 \\
\hline sensitive & 1601 & 2.58 & 1.25 & 0 & 5 \\
\hline effec & 1601 & 2.69 & 1.21 & 0 & 5 \\
\hline service & 1601 & 2.88 & 1.42 & 0 & 5 \\
\hline social_act & 1601 & 2.78 & 1.27 & 0 & 5 \\
\hline comfort & 1601 & 2.92 & 0.99 & 0 & 5 \\
\hline commit & 1601 & 2.97 & 1.03 & 0 & 5 \\
\hline distrust & 1601 & 1.85 & 1.36 & 0 & 5 \\
\hline change & 1427 & 0.31 & 0.46 & 0 & 1 \\
\hline change_good & 987 & 0.81 & 0.55 & 0 & 2 \\
\hline
\end{tabular}


Table 2

Variables definition.

\begin{tabular}{|c|c|}
\hline Variable & Definition \\
\hline trust_fin & I trust in the solvency of banks in general, and of my bank in particular. \\
\hline gender & Gender of the respondent. \\
\hline age & Age of the respondent. \\
\hline employ_situ & Employment situation of the respondent. \\
\hline educat & Education level of the respondent \\
\hline status & Perceived economic status of the respondent. \\
\hline married & Marital status of the respondent. \\
\hline income & Monthly income of all the members of the household. \\
\hline mfi_oper & Type of institution with which the individual operates more often. \\
\hline sensitive & It's sensitive to bank customers' problems. \\
\hline effec & It's effective when looking for answers to bank customers' problems. \\
\hline service & It provides better services than other nearby institutions I could go to. \\
\hline social_act & $\begin{array}{l}\text { I value social activities delivered by banks in general, and by my bank in } \\
\text { particular. }\end{array}$ \\
\hline comfort & I feel comfortable when I visit my bank. \\
\hline commit & $\begin{array}{l}\text { The bank knows that meeting its commitments with its customers is important } \\
\text { towards improving its reputation and commercial position. }\end{array}$ \\
\hline distrust & In general, I distrust people who with I do not have a close relation. \\
\hline change & $\begin{array}{l}\text { Spanish financial institutions are changing their behaviour as a consequence of } \\
\text { the current crisis. }\end{array}$ \\
\hline change_good & $\begin{array}{l}\text { Spanish financial institutions are changing their behaviour as a consequence of } \\
\text { the current crisis for the worse. }\end{array}$ \\
\hline
\end{tabular}


Table 3a

Multinomial logistic regression (Dependent Variable: trust_fin). Baseline model.

\begin{tabular}{|c|c|c|c|c|c|c|c|c|c|c|c|c|}
\hline \multirow[b]{2}{*}{ Variable } & \multicolumn{4}{|c|}{ Coefficients for bank customer characteristics } & \multicolumn{4}{|c|}{ Coefficients for the perception of bank attributes } & \multicolumn{4}{|c|}{ Coefficients for the complete baseline model } \\
\hline & trust_fin $=0$ & trust_fin $=1$ & trust_fin $=3$ & trust_fin $=4$ & trust_fin $=0$ & trust_fin $=1$ & trust_fin $=3$ & trust_fin $=4$ & trust_fin $=0$ & trust_fin $=1$ & trust_fin $=3$ & trust_fin $=4$ \\
\hline sensitive & & & & & $\begin{array}{c}-0.792^{* * * *} \\
(0.16)\end{array}$ & $\begin{array}{c}-0.341 * * \\
(0.13)\end{array}$ & $\begin{array}{c}0.357 * * \\
(0.12)\end{array}$ & $\begin{array}{c}0.810^{* * *} \\
(0.14)\end{array}$ & $\begin{array}{c}-0.771 * * * * \\
(0.16)\end{array}$ & $\begin{array}{c}-0.306^{*} \\
(0.13)\end{array}$ & $\begin{array}{c}0.405^{* * *} * \\
(0.12)\end{array}$ & $\begin{array}{c}0.881^{* * * *} \\
(0.15)\end{array}$ \\
\hline effec & & & & & $\begin{array}{c}-0.605^{* * * *} \\
(0.15)\end{array}$ & $\begin{array}{c}-0.210 \\
(0.13)\end{array}$ & $\begin{array}{c}-0.011 \\
(0.11)\end{array}$ & $\begin{array}{c}0.453 * * * \\
(0.13)\end{array}$ & $\begin{array}{c}-0.615^{* * * *} \\
(0.15)\end{array}$ & $\begin{array}{c}-0.214 \\
(0.13)\end{array}$ & $\begin{array}{c}-0.004 \\
(0.11)\end{array}$ & $\begin{array}{c}0.461 * * * \\
(0.13)\end{array}$ \\
\hline service & & & & & $\begin{array}{c}-0.132 \\
(0.15)\end{array}$ & $\begin{array}{c}-0.149 \\
(0.13)\end{array}$ & $\begin{array}{c}0.139 \\
(0.11)\end{array}$ & $\begin{array}{c}0.326^{*} \\
(0.13)\end{array}$ & $\begin{array}{c}-0.105 \\
(0.15)\end{array}$ & $\begin{array}{c}-0.110 \\
(0.13)\end{array}$ & $\begin{array}{c}0.187 \\
(0.11)\end{array}$ & $\begin{array}{c}0.395^{* *} \\
(0.14)\end{array}$ \\
\hline social_act & & & & & $\begin{array}{c}-0.259 \\
(0.14)\end{array}$ & $\begin{array}{c}-0.159 \\
(0.13)\end{array}$ & $\begin{array}{c}0.275^{*} \\
(0.11)\end{array}$ & $\begin{array}{c}0.627 * * * \\
(0.13)\end{array}$ & $\begin{array}{c}-0.266 \\
(0.15)\end{array}$ & $\begin{array}{c}-0.203 \\
(0.13)\end{array}$ & $\begin{array}{c}0.288 * * \\
(0.11)\end{array}$ & $\begin{array}{c}0.651^{* * * *} \\
(0.14)\end{array}$ \\
\hline comfort & & & & & $\begin{array}{c}-0.227 \\
(0.13)\end{array}$ & $\begin{array}{c}-0.029 \\
(0.12)\end{array}$ & $\begin{array}{l}0.151 \\
(0.11)\end{array}$ & $\begin{array}{c}0.756^{* * * *} \\
(0.14)\end{array}$ & $\begin{array}{c}-0.223 \\
(0.13)\end{array}$ & $\begin{array}{c}-0.025 \\
(0.12)\end{array}$ & $\begin{array}{l}0.156 \\
(0.11)\end{array}$ & $\begin{array}{c}0.753^{* * * *} \\
(0.15)\end{array}$ \\
\hline commit & & & & & $\begin{array}{c}-0.195 \\
(0.13)\end{array}$ & $\begin{array}{c}-0.183 \\
(0.12)\end{array}$ & $\begin{array}{c}-0.018 \\
(0.11)\end{array}$ & $\begin{array}{c}0.206 \\
(0.14)\end{array}$ & $\begin{array}{c}-0.169 \\
(0.13)\end{array}$ & $\begin{array}{c}-0.173 \\
(0.12)\end{array}$ & $\begin{array}{l}0.003 \\
(0.11)\end{array}$ & $\begin{array}{c}0.238 \\
(0.14)\end{array}$ \\
\hline distrust & & & & & $\begin{array}{l}0.039 \\
(0.16)\end{array}$ & $\begin{array}{l}0.134 \\
(0.14)\end{array}$ & $\begin{array}{l}0.134 \\
(0.12)\end{array}$ & $\begin{array}{c}0.286^{*} \\
(0.13)\end{array}$ & $\begin{array}{c}-0.011 \\
(0.16)\end{array}$ & $\begin{array}{l}0.062 \\
(0.14)\end{array}$ & $\begin{array}{c}0.104 \\
(0.12)\end{array}$ & $\begin{array}{c}0.272^{*} \\
(0.14)\end{array}$ \\
\hline gender & $\begin{array}{c}-0.405 \\
(0.31)\end{array}$ & $\begin{array}{c}-0.054 \\
(0.28)\end{array}$ & $\begin{array}{c}-0.369 \\
(0.24)\end{array}$ & $\begin{array}{c}-0.226 \\
(0.27)\end{array}$ & & & & & $\begin{array}{l}-0.125 \\
(0.33)\end{array}$ & $\begin{array}{l}0.062 \\
(0.28)\end{array}$ & $\begin{array}{c}-0.504 * \\
(0.25)\end{array}$ & $\begin{array}{l}-0.425 \\
(0.28)\end{array}$ \\
\hline age & $\begin{array}{c}-0.027 \\
(0.01)\end{array}$ & $\begin{array}{c}-0.037 * * \\
(0.01)\end{array}$ & $\begin{array}{l}-0.02 \\
(0.01)\end{array}$ & $\begin{array}{c}-0.018 \\
(0.01)\end{array}$ & & & & & $\begin{array}{l}-0.021 \\
(0.02)\end{array}$ & $\begin{array}{c}-0.033^{*} \\
(0.01)\end{array}$ & $\begin{array}{c}-0.024 * \\
(0.01)\end{array}$ & $\begin{array}{c}-0.026^{*} \\
(0.01)\end{array}$ \\
\hline employ_situ & $\begin{array}{l}0.058 \\
(0.12)\end{array}$ & $\begin{array}{l}0.026 \\
(0.11)\end{array}$ & $\begin{array}{l}0.006 \\
(0.09)\end{array}$ & $\begin{array}{l}0.168 \\
(0.11)\end{array}$ & & & & & $\begin{array}{l}0.092 \\
(0.13)\end{array}$ & $\begin{array}{l}0.034 \\
(0.11)\end{array}$ & $\begin{array}{l}0.018 \\
(0.09)\end{array}$ & $\begin{array}{l}0.186 \\
(0.11)\end{array}$ \\
\hline educat & $\begin{array}{c}-0.041 \\
(0.24)\end{array}$ & $\begin{array}{c}0.161 \\
(0.21)\end{array}$ & $\begin{array}{l}0.114 \\
(0.18)\end{array}$ & $\begin{array}{c}0.029 \\
(0.2)\end{array}$ & & & & & $\begin{array}{c}-0.162 \\
(0.25)\end{array}$ & $\begin{array}{c}0.126 \\
(0.21)\end{array}$ & $\begin{array}{c}0.16 \\
(0.18)\end{array}$ & $\begin{array}{l}0.126 \\
(0.21)\end{array}$ \\
\hline status & $\begin{array}{l}0.044 \\
(0.19)\end{array}$ & $\begin{array}{c}-0.183 \\
(0.17)\end{array}$ & $\begin{array}{l}-0.13 \\
(0.14)\end{array}$ & $\begin{array}{c}-0.075 \\
(0.16)\end{array}$ & & & & & $\begin{array}{l}0.016 \\
(0.20)\end{array}$ & $\begin{array}{c}-0.191 \\
(0.17)\end{array}$ & $\begin{array}{l}-0.068 \\
(0.15)\end{array}$ & $\begin{array}{l}0.043 \\
(0.17)\end{array}$ \\
\hline married & $\begin{array}{c}-0.179 * \\
(0.09)\end{array}$ & $\begin{array}{c}-0.028 \\
(0.08)\end{array}$ & $\begin{array}{c}-0.189 * * \\
(0.07)\end{array}$ & $\begin{array}{c}-0.185^{*} \\
(0.08)\end{array}$ & & & & & $\begin{array}{c}-0.188^{*} \\
(0.09)\end{array}$ & $\begin{array}{l}-0.027 \\
(0.08)\end{array}$ & $\begin{array}{c}-0.194 * * \\
(0.07)\end{array}$ & $\begin{array}{c}-0.185^{*} \\
(0.08)\end{array}$ \\
\hline income & $\begin{array}{c}-0.314 * * \\
(0.12)\end{array}$ & $\begin{array}{c}-0.311 * * \\
(0.10)\end{array}$ & $\begin{array}{c}-0.271 * * \\
(0.09)\end{array}$ & $\begin{array}{c}-0.401 * * * \\
(0.1)\end{array}$ & & & & & $\begin{array}{c}-0.313^{*} \\
(0.13)\end{array}$ & $\begin{array}{c}-0.304 * * \\
(0.11)\end{array}$ & $\begin{array}{c}-0.293 * * * \\
(0.09)\end{array}$ & $\begin{array}{c}-0.397 * * * \\
(0.11)\end{array}$ \\
\hline constant & $\begin{array}{c}2.546^{*} \\
(1.0)\end{array}$ & $\begin{array}{c}3.498 * * * \\
(0.88)\end{array}$ & $\begin{array}{c}4.692 * * * \\
(0.77)\end{array}$ & $\begin{array}{c}2.854 * * \\
(0.87)\end{array}$ & $\begin{array}{c}-0.607 * * \\
(0.20)\end{array}$ & $\begin{array}{c}0.652 * * * \\
(0.14)\end{array}$ & $\begin{array}{c}2.479 * * * \\
(0.12)\end{array}$ & $\begin{array}{c}0.670 * * * \\
(0.15)\end{array}$ & $\begin{array}{l}1.522 \\
(1.05)\end{array}$ & $\begin{array}{c}3.095 * * * \\
(0.89)\end{array}$ & $\begin{array}{c}4.737 * * * \\
(0.77)\end{array}$ & $\begin{array}{c}2.379 * * \\
(0.90)\end{array}$ \\
\hline No. of Obs. & \multicolumn{4}{|c|}{1601} & \multicolumn{4}{|c|}{1601} & \multicolumn{4}{|c|}{1601} \\
\hline Prob $>$ chi 2 & \multicolumn{4}{|c|}{0} & \multicolumn{4}{|c|}{0} & \multicolumn{4}{|c|}{0} \\
\hline Pseudo R2 & \multicolumn{4}{|c|}{0.02} & \multicolumn{4}{|c|}{0.11} & \multicolumn{4}{|c|}{0.14} \\
\hline Log likelihood & \multicolumn{4}{|c|}{-1970.19} & \multicolumn{4}{|c|}{-1786.57} & \multicolumn{4}{|c|}{-1741.55} \\
\hline
\end{tabular}

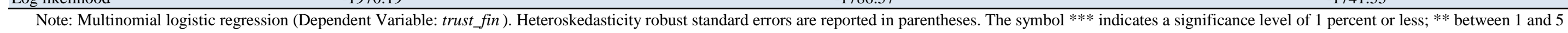

percent; * between 5 and 10 percent. The base category considered is "Neither in agreement nor disagreement" (trust_fin $=2$ ). Explanatory variables are orthogonalized. 
Table 3b

Multinomial logistic regression (Dependent Variable: trust_fin ). Baseline model.

\begin{tabular}{|c|c|c|c|c|}
\hline \multirow[b]{2}{*}{ Variable } & \multicolumn{4}{|c|}{ Marginal effects for the complete baseline model } \\
\hline & trust_fin $=0$ & trust_fin $=1$ & trust_fin $=3$ & trust_fin $=4$ \\
\hline sensitive & $\begin{array}{c}-0.0343 * * * \\
(0.00)\end{array}$ & $\begin{array}{c}-0.0604 * * * \\
(0.00)\end{array}$ & $\begin{array}{c}0.0563 * * * \\
(0.01)\end{array}$ & $\begin{array}{c}0.0488 * * * \\
(0.00)\end{array}$ \\
\hline effec & $\begin{array}{c}-0.0201 * * * \\
(0.00)\end{array}$ & $\begin{array}{c}-0.0208^{* *} \\
(0.00)\end{array}$ & $\begin{array}{c}-0.00782 \\
(0.01)\end{array}$ & $\begin{array}{c}0.0448 * * * \\
(0.00)\end{array}$ \\
\hline service & $\begin{array}{c}-0.00834^{*} \\
(0.00)\end{array}$ & $\begin{array}{c}-0.0271 * * * \\
(0.00)\end{array}$ & $\begin{array}{c}0.0186 \\
(0.01)\end{array}$ & $\begin{array}{c}0.0224 * * \\
(0.00)\end{array}$ \\
\hline social_act & $\begin{array}{c}-0.0159 * * * \\
(0.00)\end{array}$ & $\begin{array}{c}-0.0447 * * * \\
(0.00)\end{array}$ & $\begin{array}{c}0.0286^{*} \\
(0.01)\end{array}$ & $\begin{array}{c}0.0396 * * * \\
(0.00)\end{array}$ \\
\hline comfort & $\begin{array}{c}-0.0128 * * * \\
(0.00)\end{array}$ & $\begin{array}{c}-0.0191 * * \\
(0.00)\end{array}$ & $\begin{array}{c}-0.0130 \\
(0.01)\end{array}$ & $\begin{array}{c}0.0539 * * * \\
(0.00)\end{array}$ \\
\hline commit & $\begin{array}{c}-0.00534 \\
(0.00)\end{array}$ & $\begin{array}{c}-0.0177 * * \\
(0.00)\end{array}$ & $\begin{array}{c}-0.00373 \\
(0.01)\end{array}$ & $\begin{array}{c}0.0207 * \\
(0.00)\end{array}$ \\
\hline distrust & $\begin{array}{c}-0.00600 \\
(0.00)\end{array}$ & $\begin{array}{c}-0.00792 \\
(0.00)\end{array}$ & $\begin{array}{c}-0.00776 \\
(0.01)\end{array}$ & $\begin{array}{c}0.0240 * * \\
(0.00)\end{array}$ \\
\hline gender & $\begin{array}{c}0.00588 \\
(0.00)\end{array}$ & $\begin{array}{c}0.0440 * * \\
(0.01)\end{array}$ & $\begin{array}{c}-0.0743 * * \\
(0.02)\end{array}$ & $\begin{array}{c}-0.00101 \\
(0.01)\end{array}$ \\
\hline age & $\begin{array}{c}-4.73 \mathrm{e}-06 \\
(0.00)\end{array}$ & $\begin{array}{c}-0.00124 \\
(0.00)\end{array}$ & $\begin{array}{c}-0.000267 \\
(0.00)\end{array}$ & $\begin{array}{c}6.43 \mathrm{e}-05 \\
(0.00)\end{array}$ \\
\hline employ_situ & $\begin{array}{c}0.00209 \\
(0.00)\end{array}$ & $\begin{array}{c}-0.000160 \\
(0.00)\end{array}$ & $\begin{array}{c}-0.0179 \\
(0.00)\end{array}$ & $\begin{array}{c}0.0173 * \\
(0.00)\end{array}$ \\
\hline educat & $\begin{array}{c}-0.0101 \\
(0.00)\end{array}$ & $\begin{array}{c}-0.000984 \\
(0.01)\end{array}$ & $\begin{array}{c}0.0273 \\
(0.01)\end{array}$ & $\begin{array}{c}0.000807 \\
(0.01)\end{array}$ \\
\hline status & $\begin{array}{c}0.00202 \\
(0.00)\end{array}$ & $\begin{array}{c}-0.0133 \\
(0.00)\end{array}$ & $\begin{array}{c}-0.00224 \\
(0.01)\end{array}$ & $\begin{array}{c}0.0134 \\
(0.01)\end{array}$ \\
\hline married & $\begin{array}{c}-0.000322 \\
(0.00)\end{array}$ & $\begin{array}{c}0.0151 * * * \\
(0.00)\end{array}$ & $\begin{array}{c}-0.0191 * * \\
(0.00)\end{array}$ & $\begin{array}{c}-0.00308 \\
(0.00)\end{array}$ \\
\hline income & $\begin{array}{c}-0.00145 \\
(0.00)\end{array}$ & $\begin{array}{c}-0.00250 \\
(0.00)\end{array}$ & $\begin{array}{c}0.00257 \\
(0.01)\end{array}$ & $\begin{array}{c}-0.0116 \\
(0.00)\end{array}$ \\
\hline No. of Obs. & & & & \\
\hline Prob > chi2 & & & & \\
\hline Pseudo R2 & & & & \\
\hline Log likelihood & & & .55 & \\
\hline
\end{tabular}


Table 4a

Multinomial logistic regression (Dependent Variable: trust_fin) by levels of distrust.

distrust $=0$

Variable $\quad$ trust_fin $=0 \quad$ trust_fin $=1 \quad$ trust_fin $=3 \quad$ trust_fin $=4$

sensitive

effec

service

social_act

comfort

commit

constant

No. of Obs

Prob > chi2

Pseudo R2

Log likelihood

$\begin{array}{cc}-0.575 & -0.226 \\ (0.31) & (0.31) \\ -0.993 * * * & -0.611^{*} \\ (0.29) & (0.29) \\ -0.287 & 0.118 \\ (0.33) & (0.34) \\ 0.064 & -0.098 \\ (0.30) & (0.26) \\ -0.357 & 0.094 \\ (0.28) & (0.28) \\ -0.228 & -0.329 \\ (0.23) & (0.26) \\ -0.519 & 0.039 \\ (0.46) & (0.34)\end{array}$

$0.509 * \quad 0.985^{* *}$

$\begin{array}{cc}0.509^{*} & 0.985^{*} \\ (0.23) & (0.31)\end{array}$

$(0.23)$
-0.283

-0.283
$(0.20)$

0.284

(0.28)

$0.494 *$

$(0.22)$
0.084

0.084
$(0.24)$

0.017
$(0.18)$

2.194***

$(0.31)$
0.412

0.412
$(0.31)$

$0.883 * *$

$(0.33)$
$0.945 * *$

$(0.33)$

$(0.33)$
$1.116^{* *}$
$(0.43)$

$(0.43)$
0.25

(0.29)

0.178
$(0.41)$

$(0.25)$

297

0.00

$-323.15$ distrust $=1$

trust_fin $=0 \quad$ trust_fin $=1 \quad$ trust fin $=3 \quad$ trust fin $=4$

$\begin{array}{cccc}-0.937 * * & -0.484 & 0.158 & 0.838^{*} \\ (0.35) & (0.29) & (0.27) & (0.37) \\ -0.949 * * & -0.391 & -0.19 & 0.322 \\ (0.35) & (0.26) & (0.23) & (0.27) \\ -0.092 & -0.11 & 0.073 & 0.359 \\ (0.33) & (0.29) & (0.26) & (0.31) \\ -0.509 & -0.024 & 0.239 & 0.581 \\ (0.42) & (0.29) & (0.28) & (0.32) \\ -0.28 & 0.028 & 0.053 & 1.236^{* * *} \\ (0.31) & (0.25) & (0.24) & (0.35) \\ -0.024 & -0.392 & 0 & 0.666 \\ (0.33) & (0.27) & (0.26) & (0.35) \\ -0.671 & 1.049 * * * & 2.717 * * * & 0.307 \\ (0.38) & (0.27) & (0.23) & (0.32)\end{array}$

532

0.00

$-539.89$

Note: Multinomial logistic regression (Dependent Variable: trust_fin ). Heteroskedasticity robust standard errors are reported in parentheses. The symbol ***

indicates a significance level of 1 percent or less; ** between 1 and 5 percent; * between 5 and 10 percent. The base category considered is "Neither in

agreement nor disagreement" (trust_fin $=2$ ). Explanatory variables are orthogonalized. distrust $=2$

trust_fin $=0 \quad$ trust_fin $=1 \quad$ trust_fin $=3 \quad$ trust_fin $=4$

$\begin{array}{cccc}-3.354 & -0.609 & 0.672 & 4.254^{*} \\ (1.78) & (0.49) & (0.43) & (1.72) \\ -0.314 & 0.733 & -0.145 & -0.185 \\ (0.71) & (0.78) & (0.45) & (0.55) \\ 0.877 & 0.444 & 0.689 & 4.863^{* *} \\ (0.53) & (0.54) & (0.38) & (1.70) \\ -0.579 & -1.445^{*} & 0.292 & 5.063^{*} \\ (0.53) & (0.57) & (0.40) & (2.05) \\ 0.035 & 0.002 & 1.253^{*} & 5.272^{* *} \\ (0.70) & (0.55) & (0.61) & (1.68) \\ -1.680^{* *} & 0.08 & -0.631 & 2.141 \\ (0.57) & (0.79) & (0.43) & (1.56) \\ -4.434 & -1.437 & 1.786^{* * *} & -8.014 * \\ (3.14) & (0.94) & (0.5) & (3.97) \\ & & & \end{array}$

66

0.00

0.44

$-51.52$ 
Table 4b

Multinomial logistic regression (Dependent Variable: trust_fin) by levels of distrust

\begin{tabular}{|c|c|c|c|c|c|c|c|c|}
\hline \multirow[b]{2}{*}{ Variable } & \multicolumn{4}{|c|}{ distrust $=3$} & \multicolumn{4}{|c|}{ distrust $=4$} \\
\hline & trust_fin $=0$ & trust_fin $=1$ & trust_fin $=3$ & trust_fin $=4$ & trust_fin $=0$ & trust_fin $=1$ & trust_fin $=3$ & trust_fin $=4$ \\
\hline sensitive & $\begin{array}{c}-0.836^{* *} * \\
(0.32)\end{array}$ & $\begin{array}{l}-0.136 \\
(0.22)\end{array}$ & $\begin{array}{c}0.405^{*} \\
(0.20)\end{array}$ & $\begin{array}{c}0.823 * * \\
(0.27)\end{array}$ & $\begin{array}{l}-0.868 \\
(0.56)\end{array}$ & $\begin{array}{l}-0.923 \\
(0.55)\end{array}$ & $\begin{array}{l}0.127 \\
(0.49)\end{array}$ & $\begin{array}{l}0.769 \\
(0.58)\end{array}$ \\
\hline effec & $\begin{array}{l}0.001 \\
(0.36)\end{array}$ & $\begin{array}{l}0.039 \\
(0.23)\end{array}$ & $\begin{array}{c}0.388^{*} \\
(0.18)\end{array}$ & $\begin{array}{c}0.778 * * * \\
(0.24)\end{array}$ & $\begin{array}{c}-0.612 \\
(0.32)\end{array}$ & $\begin{array}{l}-0.227 \\
(0.28)\end{array}$ & $\begin{array}{l}-0.151 \\
(0.24)\end{array}$ & $\begin{array}{l}0.399 \\
(0.37)\end{array}$ \\
\hline service & $\begin{array}{c}-0.067 \\
(0.34)\end{array}$ & $\begin{array}{c}-0.389 \\
(0.26)\end{array}$ & $\begin{array}{l}0.004 \\
(0.23)\end{array}$ & $\begin{array}{c}-0.103 \\
(0.26)\end{array}$ & $\begin{array}{c}-0.518 \\
(0.39)\end{array}$ & $\begin{array}{l}-0.323 \\
(0.37)\end{array}$ & $\begin{array}{l}0.173 \\
(0.27)\end{array}$ & $\begin{array}{l}0.302 \\
(0.31)\end{array}$ \\
\hline social_act & $\begin{array}{c}-0.766 \\
(0.43)\end{array}$ & $\begin{array}{c}-0.351 \\
(0.27)\end{array}$ & $\begin{array}{l}0.152 \\
(0.25)\end{array}$ & $\begin{array}{c}0.582^{*} \\
(0.29)\end{array}$ & $\begin{array}{l}0.752 \\
(0.48)\end{array}$ & $\begin{array}{l}0.33 \\
(0.44)\end{array}$ & $\begin{array}{c}0.969^{*} \\
(0.38)\end{array}$ & $\begin{array}{c}1.193 * \\
(0.47)\end{array}$ \\
\hline comfort & $\begin{array}{c}-0.261 \\
(0.30)\end{array}$ & $\begin{array}{l}-0.08 \\
(0.23)\end{array}$ & $\begin{array}{l}0.214 \\
(0.21)\end{array}$ & $\begin{array}{c}0.602 * \\
(0.30)\end{array}$ & $\begin{array}{l}-0.432 \\
(0.34)\end{array}$ & $\begin{array}{l}-0.186 \\
(0.35)\end{array}$ & $\begin{array}{l}0.089 \\
(0.28)\end{array}$ & $\begin{array}{c}-0.078 \\
(0.32)\end{array}$ \\
\hline commit & $\begin{array}{c}-0.303 \\
(0.31)\end{array}$ & $\begin{array}{l}0.058 \\
(0.25)\end{array}$ & $\begin{array}{c}-0.019 \\
(0.24)\end{array}$ & $\begin{array}{c}-0.082 \\
(0.29)\end{array}$ & $\begin{array}{l}-0.328 \\
(0.28)\end{array}$ & $\begin{array}{c}-0.194 \\
(0.28)\end{array}$ & $\begin{array}{c}-0.146 \\
(0.20)\end{array}$ & $\begin{array}{l}0.026 \\
(0.33)\end{array}$ \\
\hline constant & $\begin{array}{c}-1.155^{* *} \\
(0.45)\end{array}$ & $\begin{array}{c}0.700 * * \\
(0.26)\end{array}$ & $\begin{array}{c}2.672 * * * \\
(0.21)\end{array}$ & $\begin{array}{c}0.768 * * \\
(0.27)\end{array}$ & $\begin{array}{l}0.641 \\
(0.76)\end{array}$ & $\begin{array}{l}1.03 \\
(0.64)\end{array}$ & $\begin{array}{c}2.808 * * * \\
(0.56)\end{array}$ & $\begin{array}{c}2.173 * * * \\
(0.64)\end{array}$ \\
\hline No. of Obs. & \multicolumn{4}{|c|}{548} & \multicolumn{4}{|c|}{139} \\
\hline Prob > chi 2 & \multicolumn{4}{|c|}{0.00} & \multicolumn{4}{|c|}{0.00} \\
\hline Pseudo R2 & \multicolumn{4}{|c|}{0.11} & \multicolumn{4}{|c|}{0.19} \\
\hline Log likelihood & \multicolumn{4}{|c|}{-578.96} & \multicolumn{4}{|c|}{-151.79} \\
\hline
\end{tabular}


Table 4c

Multinomial logistic regression (Dependent Variable: trust_fin ). Marginal effects by levels of distrust.

\begin{tabular}{|c|c|c|c|c|c|c|c|c|c|c|c|c|}
\hline \multirow[b]{2}{*}{ Variable } & \multicolumn{4}{|c|}{ distrust $=0$} & \multicolumn{4}{|c|}{ distrust $=1$} & \multicolumn{4}{|c|}{ distrust $=2$} \\
\hline & trust_fin $=0$ & trust_fin $=1$ & trust_fin $=3$ & trust_fin $=4$ & trust_fin $=0$ & trust_fin $=1$ & trust_fin $=3$ & trust_fin $=4$ & trust_fin $=0$ & trust_fin $=1$ & trust_fin $=3$ & trust_fin $=4$ \\
\hline sensitive & $\begin{array}{c}-0.0377 * * \\
(0.01)\end{array}$ & $\begin{array}{c}-0.0454 * * \\
(0.01)\end{array}$ & $\begin{array}{c}0.0559 \\
(0.02)\end{array}$ & $\begin{array}{c}0.0446^{*} \\
(0.02)\end{array}$ & $\begin{array}{c}-0.0281 * * \\
(0.00)\end{array}$ & $\begin{array}{c}-0.0746 * * * \\
(0.01)\end{array}$ & $\begin{array}{c}0.0581 * * \\
(0.02)\end{array}$ & $\begin{array}{c}0.0364 * * \\
(0.01)\end{array}$ & $\begin{array}{c}-0.0209 \\
(0.04)\end{array}$ & $\begin{array}{c}-0.0372 \\
(0.03)\end{array}$ & $\begin{array}{c}0.0822 \\
(0.06)\end{array}$ & $\begin{array}{c}0.00774 \\
(0.00)\end{array}$ \\
\hline effec & $\begin{array}{c}-0.0305 * * \\
(0.01)\end{array}$ & $\begin{array}{c}-0.0288 \\
(0.01)\end{array}$ & $\begin{array}{c}-0.0254 \\
(0.03)\end{array}$ & $\begin{array}{c}0.0687 * * \\
(0.02)\end{array}$ & $\begin{array}{c}-0.0219 * * \\
(0.00)\end{array}$ & $\begin{array}{c}-0.0251 \\
(0.01)\end{array}$ & $\begin{array}{c}0.00305 \\
(0.02)\end{array}$ & $\begin{array}{c}0.0282 * * \\
(0.01)\end{array}$ & $\begin{array}{c}-0.00252 \\
(0.00)\end{array}$ & $\begin{array}{c}0.0296 \\
(0.02)\end{array}$ & $\begin{array}{c}-0.0518 \\
(0.05)\end{array}$ & $\begin{array}{c}-0.00229 \\
(0.00)\end{array}$ \\
\hline service & $\begin{array}{c}-0.0218^{*} \\
(0.01)\end{array}$ & $\begin{array}{c}-0.0118 \\
(0.01)\end{array}$ & $\begin{array}{c}-0.00905 \\
(0.02)\end{array}$ & $\begin{array}{c}0.0628 * * * \\
(0.01)\end{array}$ & $\begin{array}{c}-0.00384 \\
(0.00)\end{array}$ & $\begin{array}{c}-0.0215 \\
(0.01)\end{array}$ & $\begin{array}{c}0.0126 \\
(0.02)\end{array}$ & $\begin{array}{c}0.0154 \\
(0.01)\end{array}$ & $\begin{array}{c}0.00425 \\
(0.00)\end{array}$ & $\begin{array}{c}-0.00306 \\
(0.01)\end{array}$ & $\begin{array}{c}0.0441 \\
(0.05)\end{array}$ & $\begin{array}{c}0.00798 \\
(0.01)\end{array}$ \\
\hline social_act & $\begin{array}{c}-0.0146 \\
(0.00)\end{array}$ & $\frac{-0.0415 * *}{(0.01)}$ & $\begin{array}{c}0.0338 \\
(0.02)\end{array}$ & $\begin{array}{c}0.0517^{*} \\
(0.02)\end{array}$ & $\begin{array}{c}-0.0202 * \\
(0.00)\end{array}$ & $\begin{array}{c}-0.0275 \\
(0.01)\end{array}$ & $\begin{array}{c}0.0294 \\
(0.02)\end{array}$ & $\begin{array}{c}0.0188 \\
(0.01)\end{array}$ & $\begin{array}{c}-0.00377 \\
(0.01)\end{array}$ & $\begin{array}{c}-0.0587 \\
(0.03)\end{array}$ & $\begin{array}{c}0.0644 \\
(0.06)\end{array}$ & $\begin{array}{c}0.00876 \\
(0.01)\end{array}$ \\
\hline comfort & $\begin{array}{c}-0.0211 * \\
(0.01)\end{array}$ & $\begin{array}{c}-0.00352 \\
(0.01)\end{array}$ & $\begin{array}{c}-0.0552 \\
(0.03)\end{array}$ & $\begin{array}{c}0.0947 * * * \\
(0.02)\end{array}$ & $\begin{array}{c}-0.0108 \\
(0.00)\end{array}$ & $\begin{array}{c}-0.00761 \\
(0.01)\end{array}$ & $\begin{array}{c}-0.0385 \\
(0.02)\end{array}$ & $\begin{array}{c}0.0607 * * * \\
(0.01)\end{array}$ & $\begin{array}{c}-0.00361 \\
(0.00)\end{array}$ & $\begin{array}{c}-0.0321 \\
(0.02)\end{array}$ & $\begin{array}{l}0.126 \\
(0.06)\end{array}$ & $\begin{array}{c}0.00823 \\
(0.00)\end{array}$ \\
\hline commit & $\begin{array}{c}-0.0118 \\
(0.00)\end{array}$ & $\begin{array}{c}-0.0263 \\
(0.01)\end{array}$ & $\begin{array}{c}0.00870 \\
(0.03)\end{array}$ & $\begin{array}{c}0.0231 \\
(0.02)\end{array}$ & $\begin{array}{c}0.000486 \\
(0.00)\end{array}$ & $\begin{array}{c}-0.0542^{* * * *} \\
(0.01)\end{array}$ & $\begin{array}{c}0.00958 \\
(0.02)\end{array}$ & $\begin{array}{c}0.0385^{* * *} \\
(0.01)\end{array}$ & $\begin{array}{c}-0.00666 \\
(0.01)\end{array}$ & $\begin{array}{c}0.0205 \\
(0.02)\end{array}$ & $\begin{array}{l}-0.125 \\
(0.06)\end{array}$ & $\begin{array}{c}0.00502 \\
(0.00)\end{array}$ \\
\hline No. of Obs. & \multirow{2}{*}{\multicolumn{4}{|c|}{297}} & \multirow{2}{*}{\multicolumn{4}{|c|}{$\begin{array}{c}532 \\
0.00\end{array}$}} & \multirow{2}{*}{\multicolumn{4}{|c|}{66}} \\
\hline Prob > chi 2 & & & & & & & & & & & & \\
\hline Pseudo R2 & \multicolumn{4}{|c|}{0.15} & \multirow{2}{*}{\multicolumn{4}{|c|}{0.15}} & \multirow{2}{*}{\multicolumn{4}{|c|}{0.44}} \\
\hline Log likelihood & \multicolumn{4}{|c|}{-323.15} & \multicolumn{2}{|c|}{-539.89} & & & \multicolumn{3}{|c|}{-51.52} & \\
\hline
\end{tabular}

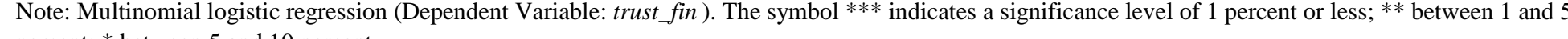
percent; * between 5 and 10 percent. 
Table 4d

Multinomial logistic regression (Dependent Variable: trust_fin ). Marginal effects by levels of distrust.

\begin{tabular}{|c|c|c|c|c|c|c|c|c|}
\hline \multirow[b]{2}{*}{ Variable } & \multicolumn{4}{|c|}{ distrust $=3$} & \multicolumn{4}{|c|}{ distrust $=4$} \\
\hline & trust_fin $=0$ & trust_fin $=1$ & trust_fin $=3$ & trust_fin $=4$ & trust_fin $=0$ & trust_fin $=1$ & trust_fin $=3$ & trust_fin $=4$ \\
\hline sensitive & $\begin{array}{c}-0.0186^{* *} \\
(0.00)\end{array}$ & $\begin{array}{c}-0.0422 * * * \\
(0.01)\end{array}$ & $\begin{array}{c}0.0344 \\
(0.02)\end{array}$ & $\begin{array}{c}0.0410 * * \\
(0.01)\end{array}$ & $\begin{array}{c}-0.0581 * * \\
(0.02)\end{array}$ & $\begin{array}{c}-0.0982 * * \\
(0.03)\end{array}$ & $\begin{array}{c}0.00248 \\
(0.04)\end{array}$ & $\begin{array}{c}0.160 * * \\
(0.05)\end{array}$ \\
\hline effec & $\begin{array}{c}-0.00633 \\
(0.00)\end{array}$ & $\begin{array}{c}-0.0297 * \\
(0.01)\end{array}$ & $\begin{array}{c}0.00753 \\
(0.02)\end{array}$ & $\begin{array}{c}0.0380 * * \\
(0.01)\end{array}$ & $\begin{array}{c}-0.0372 \\
(0.01)\end{array}$ & $\begin{array}{c}-0.0179 \\
(0.02)\end{array}$ & $\begin{array}{c}-0.0545 \\
(0.04)\end{array}$ & $\begin{array}{c}0.109 * \\
(0.05)\end{array}$ \\
\hline service & $\begin{array}{c}-0.000943 \\
(0.00)\end{array}$ & $\begin{array}{c}-0.0343^{*} \\
(0.01)\end{array}$ & $\begin{array}{c}0.0264 \\
(0.02)\end{array}$ & $\begin{array}{c}-0.00930 \\
(0.01)\end{array}$ & $\begin{array}{c}-0.0400 * \\
(0.01)\end{array}$ & $\begin{array}{c}-0.0379 \\
(0.03)\end{array}$ & $\begin{array}{c}0.0334 \\
(0.04)\end{array}$ & $\begin{array}{c}0.0490 \\
(0.04)\end{array}$ \\
\hline social_act & $\begin{array}{c}-0.0142 * \\
(0.00)\end{array}$ & $\begin{array}{c}-0.0424 * * \\
(0.01)\end{array}$ & $\begin{array}{c}0.0189 \\
(0.02)\end{array}$ & $\begin{array}{c}0.0430 * * \\
(0.01)\end{array}$ & $\begin{array}{c}-0.0111 \\
(0.02)\end{array}$ & $\begin{array}{c}-0.0626^{*} \\
(0.03)\end{array}$ & $\begin{array}{c}0.0296 \\
(0.04)\end{array}$ & $\begin{array}{c}0.0754 \\
(0.06)\end{array}$ \\
\hline comfort & $\begin{array}{c}-0.00748 \\
(0.00)\end{array}$ & $\begin{array}{c}-0.0261^{*} \\
(0.01)\end{array}$ & $\begin{array}{c}0.0124 \\
(0.02)\end{array}$ & $\begin{array}{c}0.0350 \\
(0.01)\end{array}$ & $\begin{array}{c}-0.0243 \\
(0.01)\end{array}$ & $\begin{array}{c}-0.0166 \\
(0.03)\end{array}$ & $\begin{array}{c}0.0689 \\
(0.04)\end{array}$ & $\begin{array}{c}-0.0265 \\
(0.04)\end{array}$ \\
\hline commit & $\begin{array}{c}-0.00459 \\
(0.00)\end{array}$ & $\begin{array}{c}0.00928 \\
(0.01)\end{array}$ & $\begin{array}{c}-0.00810 \\
(0.02)\end{array}$ & $\begin{array}{c}-0.0106 \\
(0.01)\end{array}$ & $\begin{array}{c}-0.00694 \\
(0.01)\end{array}$ & $\begin{array}{c}-0.00162 \\
(0.02)\end{array}$ & $\begin{array}{c}-0.0140 \\
(0.03)\end{array}$ & $\begin{array}{c}0.0201 \\
(0.04)\end{array}$ \\
\hline No. of Obs. & \multicolumn{4}{|c|}{548} & \multicolumn{4}{|c|}{139} \\
\hline Prob > chi2 & \multicolumn{4}{|c|}{0.00} & \multicolumn{4}{|c|}{0.00} \\
\hline Pseudo R2 & \multicolumn{4}{|c|}{0.11} & \multicolumn{4}{|c|}{0.19} \\
\hline Log likelihood & \multicolumn{4}{|c|}{-578.96} & \multicolumn{4}{|c|}{-151.79} \\
\hline
\end{tabular}

Note: Multinomial logistic regression (Dependent Variable: trust_fin). The symbol *** indicates a significance level of 1 percent or less; $* *$ between 1 and 5 percent; * between 5 and 10 percent. 
Table 5a

Multinomial logistic regression (Dependent Variable: trust_fin) by type of financial institution.

\begin{tabular}{|c|c|c|c|c|c|c|c|c|}
\hline \multirow[b]{2}{*}{ Variable } & \multicolumn{2}{|c|}{ trust_fin $=0$} & \multicolumn{2}{|c|}{ trust_fin $=1$} & \multicolumn{2}{|c|}{ trust_fin $=3$} & \multicolumn{2}{|c|}{ trust_fin $=4$} \\
\hline & commercial banks & savings banks & commercial banks & savings banks & commercial banks & savings banks & commercial banks & savings banks \\
\hline sensitive & $\begin{array}{c}-0.786 * * \\
(0.28)\end{array}$ & $\begin{array}{c}-0.812 * * * \\
(0.2)\end{array}$ & $\begin{array}{l}-0.03 \\
(0.2)\end{array}$ & $\begin{array}{c}-0.514 * * \\
(0.17)\end{array}$ & $\begin{array}{c}0.599 * * * \\
(0.18)\end{array}$ & $\begin{array}{l}0.239 \\
(0.15)\end{array}$ & $\begin{array}{c}0.836 * * * \\
(0.24)\end{array}$ & $\begin{array}{c}0.867 * * * \\
(0.2)\end{array}$ \\
\hline effec & $\begin{array}{c}-0.34 \\
(0.27)\end{array}$ & $\begin{array}{c}-0.776^{* * * *} \\
(0.2)\end{array}$ & $\begin{array}{c}-0.264 \\
(0.22)\end{array}$ & $\begin{array}{c}-0.262 \\
(0.15)\end{array}$ & $\begin{array}{c}0.209 \\
(0.17)\end{array}$ & $\begin{array}{c}-0.106 \\
(0.13)\end{array}$ & $\begin{array}{c}0.571 * \\
(0.24)\end{array}$ & $\begin{array}{c}0.393 * \\
(0.17)\end{array}$ \\
\hline service & $\begin{array}{c}0.152 \\
(0.27)\end{array}$ & $\begin{array}{c}-0.207 \\
(0.21)\end{array}$ & $\begin{array}{c}-0.306 \\
(0.25)\end{array}$ & $\begin{array}{c}-0.074 \\
(0.18)\end{array}$ & $\begin{array}{c}0.273 \\
(0.22)\end{array}$ & $\begin{array}{l}0.117 \\
(0.15)\end{array}$ & $\begin{array}{l}0.362 \\
(0.25)\end{array}$ & $\begin{array}{c}0.408^{*} \\
(0.18)\end{array}$ \\
\hline social_act & $\begin{array}{c}-0.324 \\
(0.3)\end{array}$ & $\begin{array}{c}-0.177 \\
(0.24)\end{array}$ & $\begin{array}{c}-0.183 \\
(0.22)\end{array}$ & $\begin{array}{c}-0.131 \\
(0.19)\end{array}$ & $\begin{array}{c}0.314 \\
(0.2)\end{array}$ & $\begin{array}{l}0.29 \\
(0.17)\end{array}$ & $\begin{array}{c}0.515^{*} \\
(0.239\end{array}$ & $\begin{array}{c}0.800 * * * \\
(0.22)\end{array}$ \\
\hline comfort & $\begin{array}{l}-0.06 \\
(0.21)\end{array}$ & $\begin{array}{l}-0.37 \\
(0.19)\end{array}$ & $\begin{array}{c}0.224 \\
(0.2)\end{array}$ & $\begin{array}{c}-0.164 \\
(0.15)\end{array}$ & $\begin{array}{l}0.204 \\
(0.18)\end{array}$ & $\begin{array}{l}0.086 \\
(0.14)\end{array}$ & $\begin{array}{c}0.580 * \\
(0.259\end{array}$ & $\begin{array}{c}0.809 * * * \\
(0.23)\end{array}$ \\
\hline commit & $\begin{array}{c}-0.099 \\
(0.2)\end{array}$ & $\begin{array}{c}-0.236 \\
(0.2)\end{array}$ & $\begin{array}{c}-0.213 \\
(0.18)\end{array}$ & $\begin{array}{c}-0.171 \\
(0.17)\end{array}$ & $\begin{array}{c}-0.014 \\
(0.16)\end{array}$ & $\begin{array}{c}-0.001 \\
(0.16)\end{array}$ & $\begin{array}{c}0.465^{*} \\
(0.23)\end{array}$ & $\begin{array}{c}0.042 \\
(0.2)\end{array}$ \\
\hline distrust & $\begin{array}{c}0.355 \\
(0.27)\end{array}$ & $\begin{array}{c}-0.025 \\
(0.22)\end{array}$ & $\begin{array}{c}0.081 \\
(0.24)\end{array}$ & $\begin{array}{c}0.157 \\
(0.17)\end{array}$ & $\begin{array}{c}0.007 \\
(0.21)\end{array}$ & $\begin{array}{c}0.174 \\
(0.15)\end{array}$ & $\begin{array}{c}0.246 \\
(0.24)\end{array}$ & $\begin{array}{l}0.245 \\
(0.17)\end{array}$ \\
\hline constant & $\begin{array}{c}-0.781 \\
(0.43)\end{array}$ & $\begin{array}{c}-0.589 * \\
(0.26)\end{array}$ & $\begin{array}{l}0.441 \\
(0.28)\end{array}$ & $\begin{array}{c}0.727 * * * \\
(0.18)\end{array}$ & $\begin{array}{c}2.446 * * * \\
(0.23)\end{array}$ & $\begin{array}{c}2.529 * * * \\
(0.15)\end{array}$ & $\begin{array}{c}0.934 * * * \\
(0.27)\end{array}$ & $\begin{array}{c}0.495^{*} \\
(0.22)\end{array}$ \\
\hline No. of Obs. & 487 & 1055 & 487 & 1055 & 487 & 1055 & 487 & 1055 \\
\hline Prob $>$ chi 2 & 0 & 0 & 0 & 0 & 0 & 0 & 0 & 0 \\
\hline Pseudo R2 & 0.15 & 0.12 & 0.15 & 0.12 & 0.15 & 0.12 & 0.15 & 0.12 \\
\hline Log likelihood & -545.52 & -1152.78 & -545.52 & -1152.78 & -545.52 & -1152.78 & -545.52 & -1152.78 \\
\hline
\end{tabular}

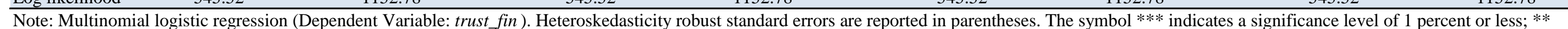
between 1 and 5 percent; * between 5 and 10 percent. The base category considered is "Neither in agreement nor disagreement" (trust_fin $=2$ ). Explanatory variables are orthogonalized. 


\section{Table 5b}

Multinomial logistic regression (Dependent Variable: trust_fin). Marginal effects by type of financial institution.

\begin{tabular}{|c|c|c|c|c|c|c|c|c|}
\hline \multirow[b]{2}{*}{ Variable } & \multicolumn{2}{|c|}{ trust_fin $=0$} & \multicolumn{2}{|c|}{ trust_fin $=1$} & \multicolumn{2}{|c|}{ trust_fin $=3$} & \multicolumn{2}{|c|}{ trust_fin $=4$} \\
\hline & commercial banks & savings banks & commercial banks & savings banks & commercial banks & savings banks & commercial banks & savings banks \\
\hline sensitive & $\begin{array}{c}-0.0448 * * * \\
(0.00)\end{array}$ & $\begin{array}{c}-0.0269 * * * \\
(0.00)\end{array}$ & $\begin{array}{c}-0.0497 * * * \\
(0.01)\end{array}$ & $\begin{array}{c}-0.0693 * * * \\
(0.00)\end{array}$ & $\begin{array}{c}0.0814 * * * \\
(0.02)\end{array}$ & $\begin{array}{c}0.0416^{* * *} \\
(0.01)\end{array}$ & $\begin{array}{c}0.0381 * \\
(0.01)\end{array}$ & $\begin{array}{c}0.0536 * * * \\
(0.01)\end{array}$ \\
\hline effec & $\begin{array}{c}-0.0179 * \\
(0.00)\end{array}$ & $\begin{array}{c}-0.0205 * * * \\
(0.00)\end{array}$ & $\begin{array}{c}-0.0427 * * \\
(0.01)\end{array}$ & $\begin{array}{c}-0.0165 \\
(0.00)\end{array}$ & $\begin{array}{c}0.0150 \\
(0.02)\end{array}$ & $\begin{array}{c}-0.0117 \\
(0.01)\end{array}$ & $\begin{array}{c}0.0483 * \\
(0.01)\end{array}$ & $\begin{array}{c}0.0401 * * * \\
\quad(0.00)\end{array}$ \\
\hline service & $\begin{array}{c}-0.00203 \\
(0.00)\end{array}$ & $\begin{array}{c}-0.00905 \\
(0.00)\end{array}$ & $\begin{array}{c}-0.0509 * * * \\
(0.01)\end{array}$ & $\begin{array}{c}-0.0197 \\
(0.01)\end{array}$ & $\begin{array}{c}0.0449 \\
(0.02)\end{array}$ & $\begin{array}{c}0.00117 \\
(0.01)\end{array}$ & $\begin{array}{c}0.0164 \\
(0.01)\end{array}$ & $\begin{array}{c}0.0256^{* *} \\
(0.00)\end{array}$ \\
\hline social_act & $\begin{array}{c}-0.0184^{*} \\
(0.00)\end{array}$ & $\begin{array}{c}-0.0126^{*} \\
(0.00)\end{array}$ & $\begin{array}{c}-0.0416 * * * \\
(0.01)\end{array}$ & $\begin{array}{c}-0.0409 * * * \\
(0.01)\end{array}$ & $\begin{array}{c}0.0358 \\
(0.02)\end{array}$ & $\begin{array}{c}0.0197 \\
(0.01)\end{array}$ & $\begin{array}{c}0.0297 * \\
(0.01)\end{array}$ & $\begin{array}{c}0.0471 * * * \\
(0.01)\end{array}$ \\
\hline comfort & $\begin{array}{c}-0.0104 \\
(0.00)\end{array}$ & $\begin{array}{c}-0.0142 * * \\
(0.00)\end{array}$ & $\begin{array}{c}0.00100 \\
(0.01)\end{array}$ & $\begin{array}{c}-0.0267 * * \\
(0.00)\end{array}$ & $\begin{array}{c}-0.0179 \\
(0.02)\end{array}$ & $\begin{array}{c}-0.0105 \\
(0.01)\end{array}$ & $\begin{array}{c}0.0412 * \\
(0.01)\end{array}$ & $\begin{array}{c}0.0578 * * * \\
(0.01)\end{array}$ \\
\hline commit & $\begin{array}{c}-0.00388 \\
(0.00)\end{array}$ & $\begin{array}{c}-0.00610 \\
(0.00)\end{array}$ & $\begin{array}{c}-0.0234 \\
(0.01)\end{array}$ & $\begin{array}{c}-0.0152 \\
(0.00)\end{array}$ & $\begin{array}{c}-0.0216 \\
(0.02)\end{array}$ & $\begin{array}{c}0.00515 \\
(0.01)\end{array}$ & $\begin{array}{c}0.0515^{* *} * \\
(0.01)\end{array}$ & $\begin{array}{c}0.00189 \\
(0.01)\end{array}$ \\
\hline distrust & $\begin{array}{c}0.00902 \\
(0.00)\end{array}$ & $\begin{array}{c}-0.00887 \\
(0.00)\end{array}$ & $\begin{array}{c}-0.00578 \\
(0.01)\end{array}$ & $\begin{array}{c}-0.00670 \\
(0.00)\end{array}$ & $\begin{array}{c}-0.0344 \\
(0.02)\end{array}$ & $\begin{array}{c}0.00289 \\
(0.01)\end{array}$ & $\begin{array}{c}0.0306 \\
(0.01)\end{array}$ & $\begin{array}{c}0.0156 \\
(0.00)\end{array}$ \\
\hline No. of Obs. & 487 & 1055 & 487 & 1055 & 487 & 1055 & 487 & 1055 \\
\hline Prob > chi 2 & 0 & 0 & 0 & 0 & 0 & 0 & 0 & 0 \\
\hline Pseudo R2 & 0.15 & 0.12 & 0.15 & 0.12 & 0.15 & 0.12 & 0.15 & 0.12 \\
\hline Log likelihood & -545.52 & -1152.78 & -545.52 & -1152.78 & -545.52 & -1152.78 & -545.52 & -1152.78 \\
\hline
\end{tabular}

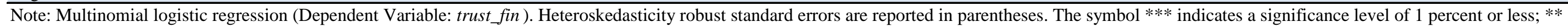
between 1 and 5 percent; * between 5 and 10 percent. 


\section{Table 6}

Marginal effects of sensitive on trust_fin by level of distrust under bank customers' assumption that Spanish financial institutions are changing their behaviour for the worse as a consequence of the current crisis.

\begin{tabular}{lcccc}
\hline & \multicolumn{4}{c}{ Changes in Probabilities for trust_fin } \\
sensitive & trust_fin $=0$ & trust_fin $=1$ & trust_fin $=3$ & trust_fin $=4$ \\
\hline distrust $=0$ & -0.090 & -0.080 & 0.066 & 0.132 \\
distrust $=1$ & -0.026 & -0.099 & 0.057 & 0.061 \\
distrust $=2$ & 0.000 & 0.000 & 0.347 & 0.000 \\
distrust $=3$ & -0.003 & -0.072 & 0.040 & 0.054 \\
distrust $=4$ & -0.137 & -0.185 & 0.170 & 0.154 \\
\hline
\end{tabular}

Table 7

Marginal effects of effec on trust_fin by level of distrust under bank customers' assumption that Spanish financial institutions are changing their behaviour for the worse as a consequence of the current crisis.

\begin{tabular}{|c|c|c|c|c|}
\hline \multirow[b]{2}{*}{ effec } & \multicolumn{4}{|c|}{ Changes in Probabilities for trust_fin } \\
\hline & trust_fin $=0$ & trust_fin $=1$ & trust_fin $=3$ & trust_fin $=4$ \\
\hline distrust $=0$ & -0.028 & 0.041 & -0.090 & 0.030 \\
\hline distrust $=1$ & -0.017 & -0.022 & -0.036 & 0.066 \\
\hline distrust $=2$ & 0.000 & 0.000 & 0.166 & 0.000 \\
\hline distrust $=3$ & -0.004 & -0.024 & -0.003 & 0.039 \\
\hline distrust $=4$ & -0.043 & -0.029 & -0.088 & 0.156 \\
\hline
\end{tabular}




\section{Table 8}

Marginal effects of service on trust_fin by level of distrust under bank customers' assumption that Spanish financial institutions are changing their behaviour for the worse as a consequence of the current crisis.

\begin{tabular}{lcccc}
\hline & \multicolumn{4}{c}{ Changes in Probabilities for trust_fin } \\
service & trust_fin $=0$ & trust_fin $=1$ & trust_fin $=3$ & trust_fin $=4$ \\
\hline distrust $=0$ & -0.034 & -0.031 & 0.016 & 0.039 \\
distrust $=1$ & -0.002 & -0.005 & -0.016 & 0.024 \\
distrust $=2$ & 0.000 & 0.000 & 0.228 & 0.000 \\
distrust $=3$ & 0.001 & -0.002 & 0.001 & 0.011 \\
distrust $=4$ & -0.107 & -0.119 & 0.095 & 0.130 \\
\hline
\end{tabular}

Table 9

Marginal effects of social_act on trust_fin by level of distrust under bank customers' assumption that Spanish financial institutions are changing their behaviour for the worse as a consequence of the current crisis.

\begin{tabular}{lcccc}
\hline & \multicolumn{4}{c}{ Changes in Probabilities for trust_fin } \\
social_act & trust_fin $=0$ & trust_fin $=1$ & trust_fin $=3$ & trust_fin $=4$ \\
\hline distrust $=0$ & -0.002 & -0.084 & 0.121 & 0.038 \\
distrust $=1$ & -0.019 & -0.038 & 0.026 & 0.031 \\
distrust $=2$ & 0.000 & 0.000 & 0.141 & 0.000 \\
distrust $=3$ & 0.000 & -0.021 & 0.003 & 0.032 \\
distrust $=4$ & -0.028 & -0.063 & 0.087 & 0.012 \\
\hline
\end{tabular}




\section{Table 10}

Marginal effects of confort on trust_fin by level of distrust under bank customers' assumption that Spanish financial institutions are changing their behaviour for the worse as a consequence of the current crisis.

\begin{tabular}{lcccc}
\hline & \multicolumn{4}{c}{ Changes in Probabilities for trust_fin } \\
comfort & trust_fin $=0$ & trust_fin $=1$ & trust_fin $=3$ & trust_fin $=4$ \\
\hline distrust $=0$ & -0.051 & 0.044 & -0.050 & 0.018 \\
distrust $=1$ & -0.009 & -0.014 & -0.029 & 0.058 \\
distrust $=2$ & 0.000 & 0.000 & 0.003 & 0.000 \\
distrust $=3$ & -0.001 & -0.044 & 0.050 & -0.002 \\
distrust $=4$ & -0.023 & -0.002 & 0.013 & 0.009 \\
\hline
\end{tabular}

\section{Table 11}

Marginal effects of commit on trust_fin by level of distrust under bank customers' assumption that Spanish financial institutions are changing their behaviour for the worse as a consequence of the current crisis.

\begin{tabular}{lcccc}
\hline & \multicolumn{4}{c}{ Changes in Probabilities for trust_fin } \\
commit & trust_fin $=0$ & trust_fin $=1$ & trust_fin $=3$ & trust_fin $=4$ \\
\hline distrust $=0$ & -0.010 & 0.003 & 0.000 & 0.009 \\
distrust $=1$ & 0.000 & -0.045 & 0.009 & 0.041 \\
distrust $=2$ & 0.000 & 0.000 & 0.340 & 0.000 \\
distrust $=3$ & -0.001 & -0.003 & -0.008 & 0.000 \\
distrust $=4$ & -0.023 & -0.049 & 0.023 & 0.049 \\
\hline
\end{tabular}

